


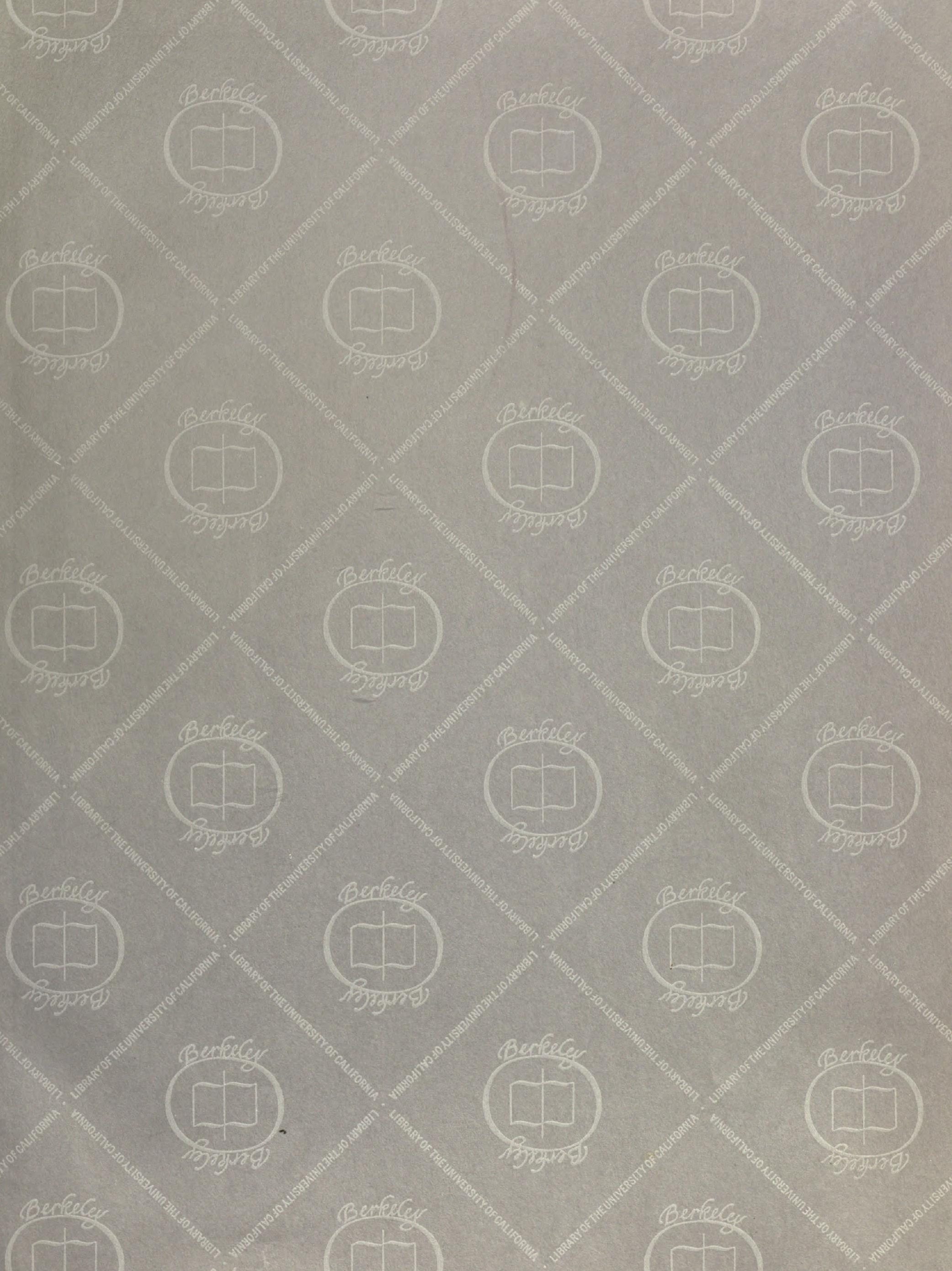





WILD FLOWERS OF THE PACIFIC COAST 



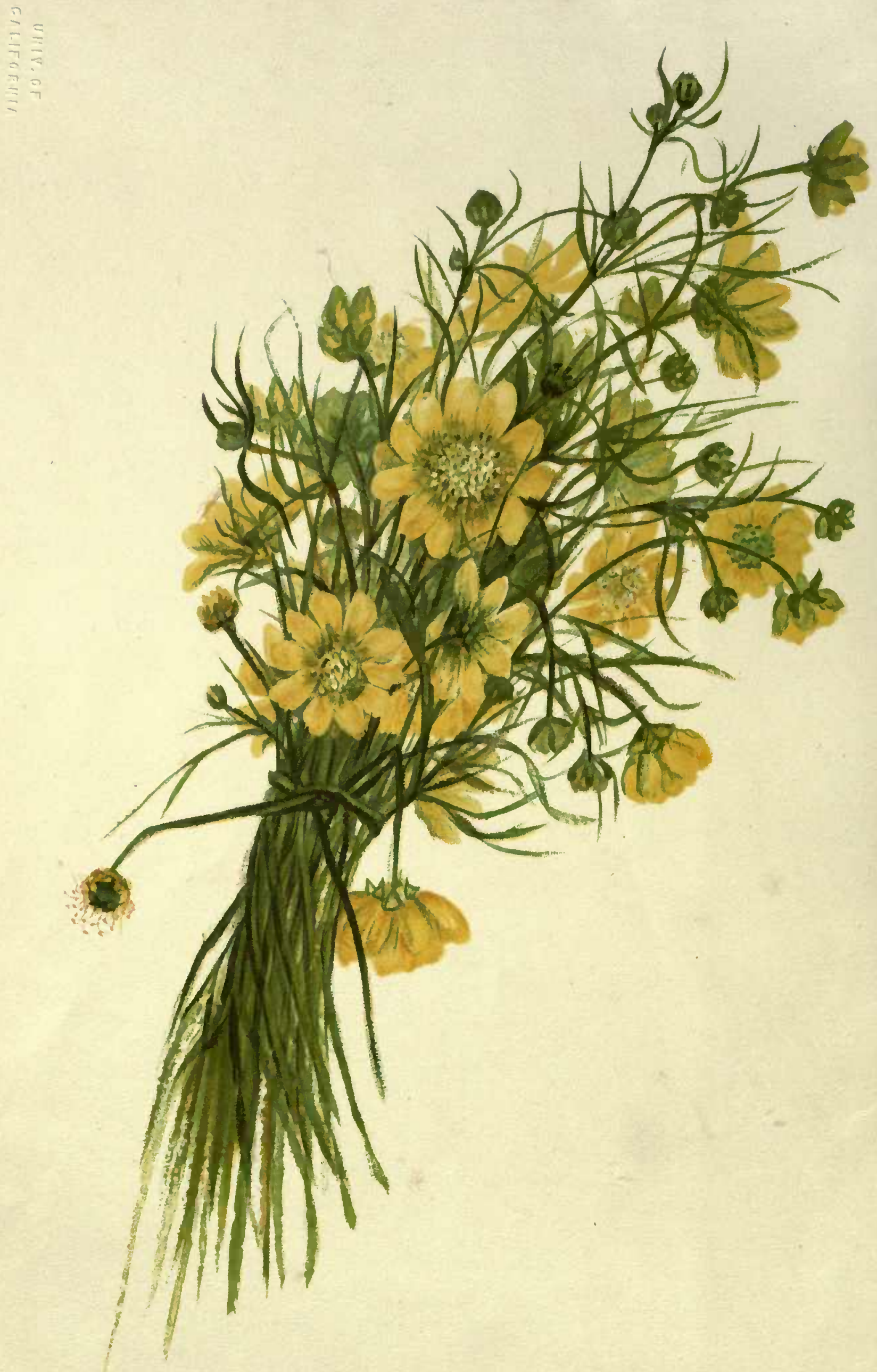




\section{WHD HIOWHRS}

\section{THE PACIFIC COAST}

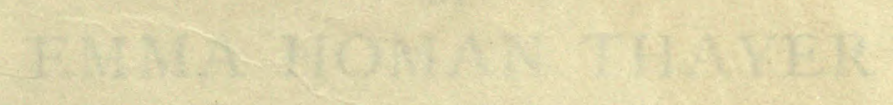





\section{WILD FLOWERS}

or

\section{THE PACIFIC COAST}

FROM ORIGINAL WATER COLOR SKETCHES DRAWN FROM NATURE

BY

EMMA HOMAN THAYER

aUthor OF "Wild FLowers of the rocky mountains," etc.

CASSELL \& COMPANY, Limited,

$739 \& 741$ Broadway, New York. 


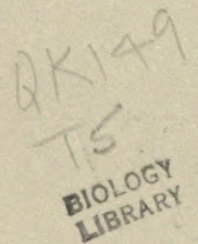

\section{BIOLOGY LIBRARY}

$$
\text { Replacing } 121074
$$

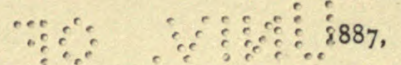

Bx O. M.-DUNHAM.

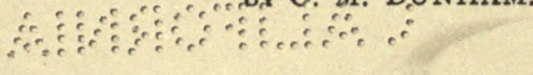

ALL RIGHTS RESERVED.

Chromo-Lithographed by Donaldson Brothers, New York. Press W. L. Mershon \& Co., Rahway, N. J. 
I DEDICATE THIS BOOK TO THE MEMORY OF MY FATHER

GEORGE W. HOMAN. 



\section{INTRODUCTION.}

In presenting this collection of Wild Flowers, I have selected those from my sketches that are most beloved by the people of the coast, and are new and of interest to lovers of wild flowers in the East.

I have given them to you as I found them growing in their natural simplicity along the trails of the mountains, and by the streams in the valleys.

They are but a handful compared to the multitude we find all aiong the coast. All the varieties of the East are found here. There is no peak so high, or valley so deep, but you see their lovely faces waiting to welcome you. They smile and nod as if inviting you to catch them. You reach up to pluck one, and you discover a bright-colored neighbor beckoning you higher, and so you climb to the very top, all unconscious of the dizzy height, lured on by these bright-arrayed children of the mountains.

In the places most difficult of access I found the most beautiful flowers. It would seem as if they wished to hide the delicate members of their family from the rude gaze of the world, sheltered in some nook of the rocks, like a miniature conservatory tenderly cared for by the fairies of the mountains.

Often you will see a most beautiful specimen growing just beyond your reach on some rugged point. The desire to possess it is so great you can hardly resist the dangerous reach. I once saw a whole bed of fine bell-shape flowers on a point above me, impossible to climb. I had spent days in trying to find this variety, and here they were a few feet above my head, but no human hand could touch them. They grew wondrously beautiful while I gazed, and I imagined they grew larger and larger until they looked like a whole chime of bells ringing out a dirge to my disappointed ambitions.

In Southern California you can pick wild flowers every month in the year, and in February they make their appearance all over the state, and continue their line of march up the coast, and by April you find them in the fields and woods of Oregon.

To those who are familiar with the flowers of California, may they welcome these in my collection as old friends, and to those who are strangers, may they prove an introduction to the home of the beautiful wild flowers of the Pacific Coast.

E. H. T. 


\section{LIST OF PLATES.}

BUtTercups. Ranunculaceae

EVENING PRIMROSE. Ó nagraceae BURR-CLOVER.

BABY BLUE EyEs. Hydrophyllaceae

yELLOW POPPy. Papaveraceae

LARKSPUR. Ranancwaceae

WILD THRIFT.

Cluster hily. Liliaceae

VIOLET.

WILd VERBENA. Verbenaceac

BLUE BELLS.

SNAP-DRAGON.

SHOOTING STAR. Primulaceae

WILD PEONY.

CHINESE CIGARETTE BLOSSOM.

WILD HELIOTROPE.

"tIDy-tips." Astevaceae (Compositae)

SNOW PLANT. Ericaceae;

FORGET-ME-NOT.

wOOd LILy. Liliaceae

AZALEA. Ericaceae

spotted Lily. Liliaceae

SALMON BLOSSOMS AND PINK GRASS.

MARIPOSA LILy. Lifiaceae 


\section{Wild Flowers of the Pacific Coast.}

\section{BUTTERCUPS.}

As our train nears San Francisco we run on the long pier far out in the bay, and as we board one of the fine ferryboats, a friend directs us to the front and says:

"You get a finer view here." We have an indistinct remembrance of his continuing to talk, but in our surprise and delight at the view we do not hear him. The magnificent bay is before us. In the distance we see the city of San Francisco, with its hundred of spires tipped with brasses shining out in the sun. The bay is as smooth as a mirror, stately ocean ships and "men-of-war" are coming in or going out:" The ferry-boats, so large and fine, they remind us of the Boston steamboats in size and grandeur. Yachts and fishing smacks lie side by side, and the saucy little tug goes flying in and out, peeping here and there in her inquisitive way, as if wishing to know her neighbors' business.

Flags are flying, and every nation is represented, but with their colors we see a flag that seems to act as host and guardian, and we recognize the Stars and Stripes.

White-winged birds fly abreast our boat and lead the way, as if bidding us a welcome. How beautiful it is, and we seat 
ourselves comfortably to enjoy it all, when we are gently touched upon the arm, and a voice low but distinct asks :

"Grand Hotel ?" and the notes echo from every side, the first word changed, but the last ever the same- "Palace Hotel?" "Occidental Hotel ?" We stop the echo by saying, "Occidental Hotelpease." Our hand-bag and bundles disappear, and when vive land the same quiet voice directs us to the coach, and we are wheeled away through the business portion of San Francisco, and landed in the reception-room of the Occidental.

Not a moment is lost, you are shown a room and there you find your bags and bundles, which give it a home look, and you are left with a "Hope you'll find every thing comfortable, ma'm," which makes you feel the boy's your friend.

I prepare for lunch, and the lonely feeling is just beginning to creep stealthily in when a rap is heard, which startles it. The door is opened, and a kind voice says, "Wid de compliments of Maj. Hooper, de pro-prietor of dis hotel," and a basket is placed upon my table filled with buttercups fresh cut, with odors of new mown hay and suggestions of country fields and brighteyed daisies about them.

The lonely feeling disappears. I select a bunch from the basket and arrange them for my belt, and am about to stab them with the long pin, when I change my mind. No! I will paint them instead, they shall be my first sketch, and so my first day spent in San Francisco was devoted to this little bunch of buttercups that came from the fields back of Oakland. 




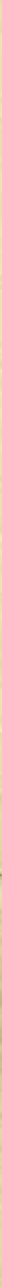





\section{EVENING PRIMROSE.}

The second day after my arrival in Sacramento, I was told of a little Scotch girl who knew every wild flower for miles around, and at one of the flower festivals she had sent a great variety of them beautifully arranged, and they were so much admired her name had been mentioned in a complimentary manner in the city papers.

Through a mutual friend I made the acquaintance of the little girl-Jennie McClure. A call upon her, and we became friends at once. We made an engagement to go the next day in search of primroses. "Yes, she knew just where they grew, lovely white ones. We would have to walk quite a bit if I did not mind."

I did " not mind." I was to call for Jennie at ten the next morning, but long before that hour she came for me.

"I thought you had forgot the time, and I'd come on a bit and meet you!"

"No, Jennie, I did not forget the hour. I was just starting when I saw you coming, but I am glad you came. I shall have your company so much the longer."

"Do you mind if I take Tom with us? He is my brother, and always goes with me when I go for flowers," and the sweet face brightened while she waited for my answer.

"Have him come with us by all means. Where is he?"

"I felt most sure you'd like him to go, and I told him to 
pick a basket of oranges. We'll get so dry, walking in the sun, and after we eat the oranges we can put the flowers in the basket. Oh, here he comes! Tom, this is the lady, and she likes you to go," and Jennie brought him forward in the most motherly manner for his introduction.

We took the street cars out to the edge of the town, and then Tom led the way, while Jennie talked constantly, telling me of their many trips after flowers; and she knew the exact place to find the primroses, she had seen them "hundreds of times." "You know, Tom, it is just the other side of the big flow." "Yes, Jennie, I know presaxley. Is the lady afraid of snakes?"

"Yes, Tom, I am. Why?" I asked in alarm.

"'Cause a bit to the left is a nest of 'um. I killed one on our last trip. Do you mind, Jennie?"

"Yes, I do, Tom. But Papa said if we ran crooked, like this, they would not come out," and Jennie gathered up her short skirts and started. I followed, but Tom walked straight in the middle of the road in a most dignified manner. He carried a stick in his hand almost as large as himself, ready to defend us, did the snake make his appearance. But none came out, and we walked on again in safety, I to listen to wonderful snake stories from Tom, who, being only "ten, but going on eleven," had had wonderful experiences for one of his years.

The "big flow" was reached; Tom helped me over the stepping-stones safely, and the dainty "beauties" were soon dug up and nestling lovingly in my basket. 


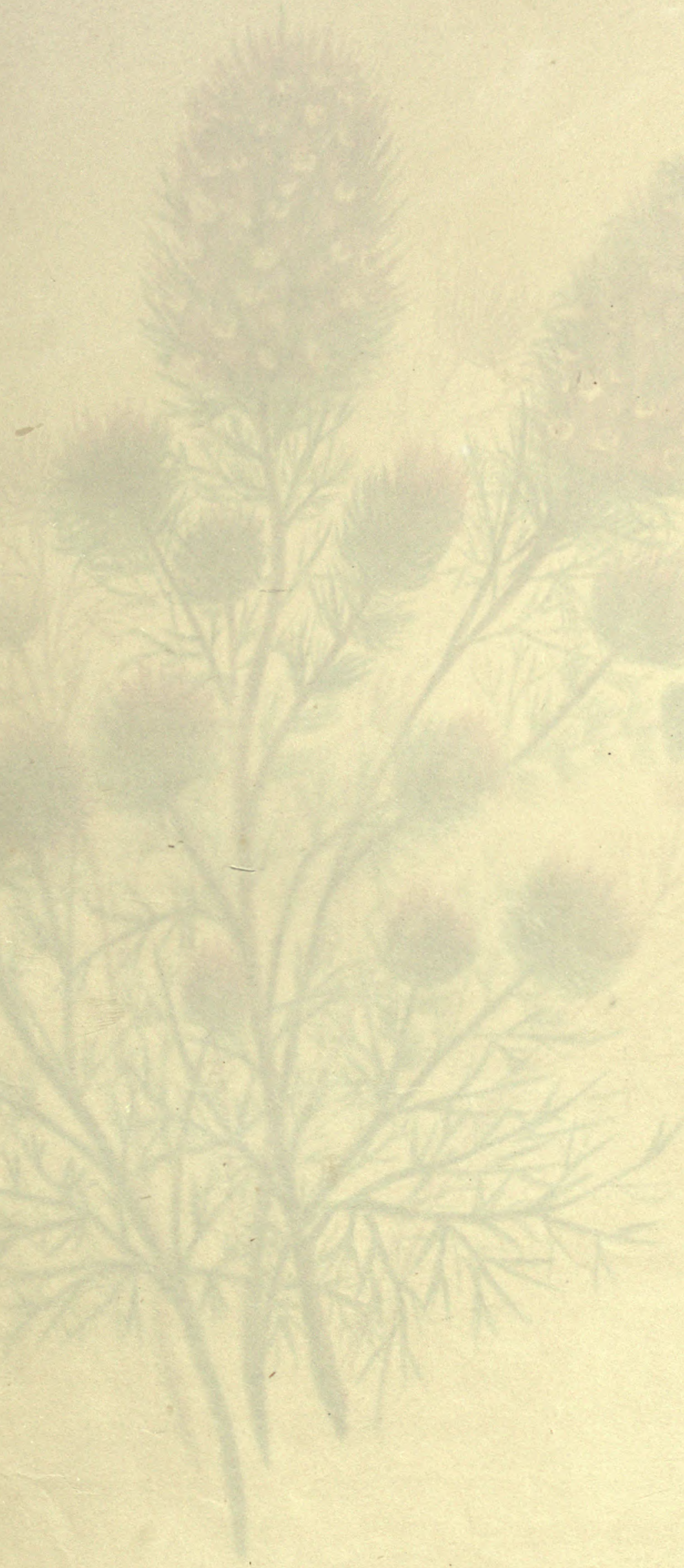




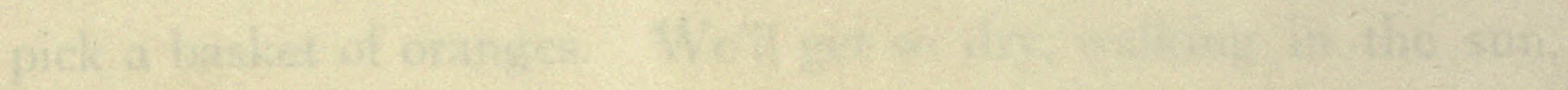

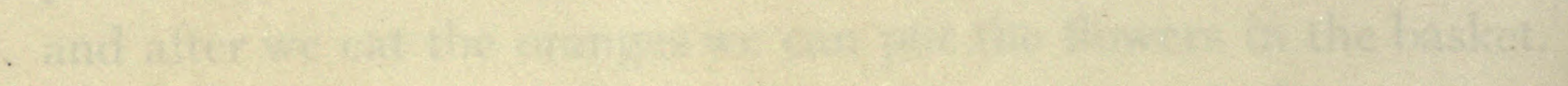
(0)

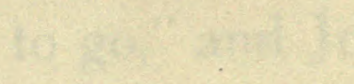

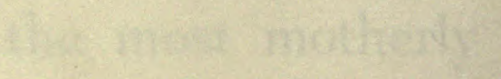

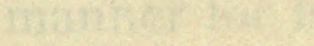

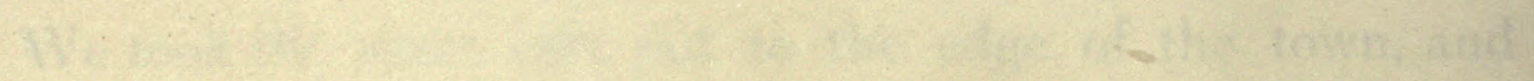

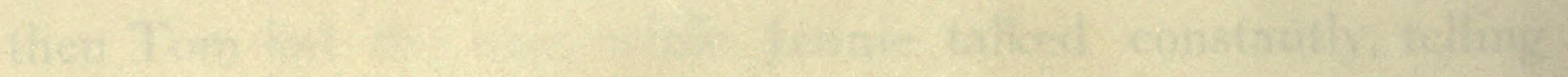

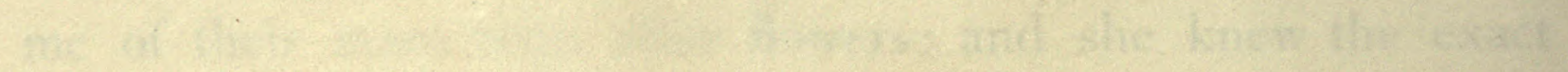

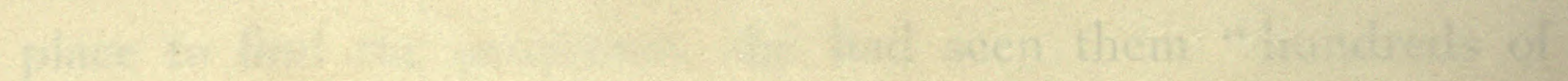

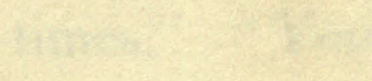

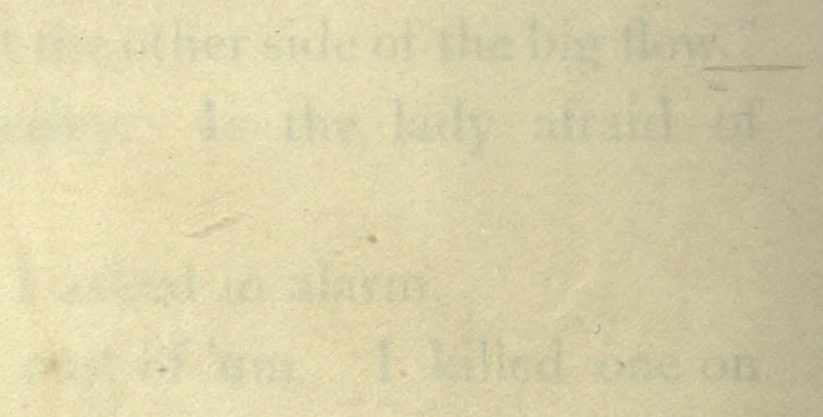

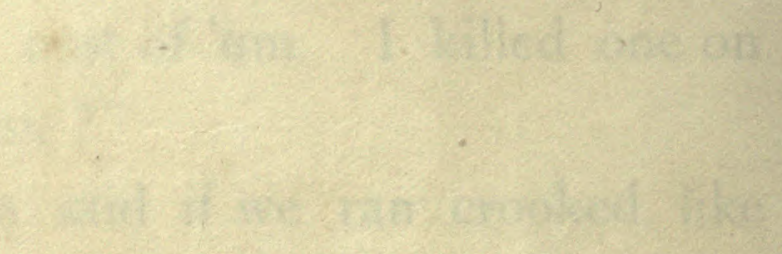

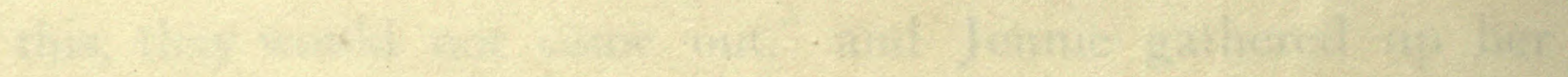

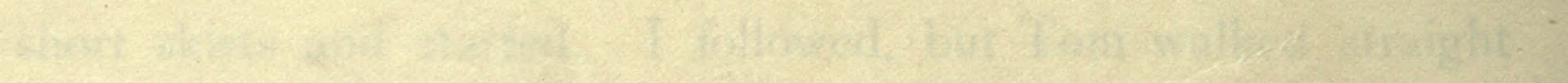

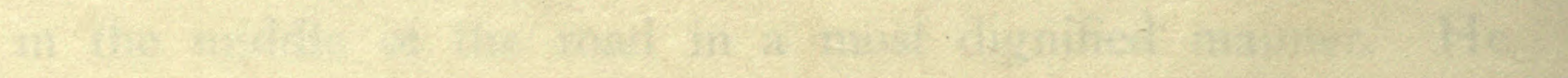

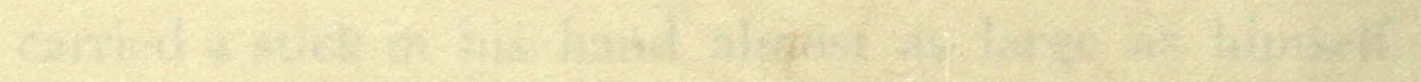

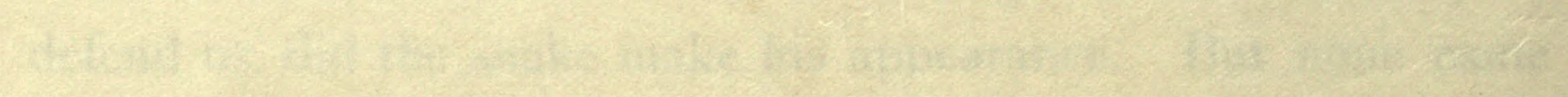




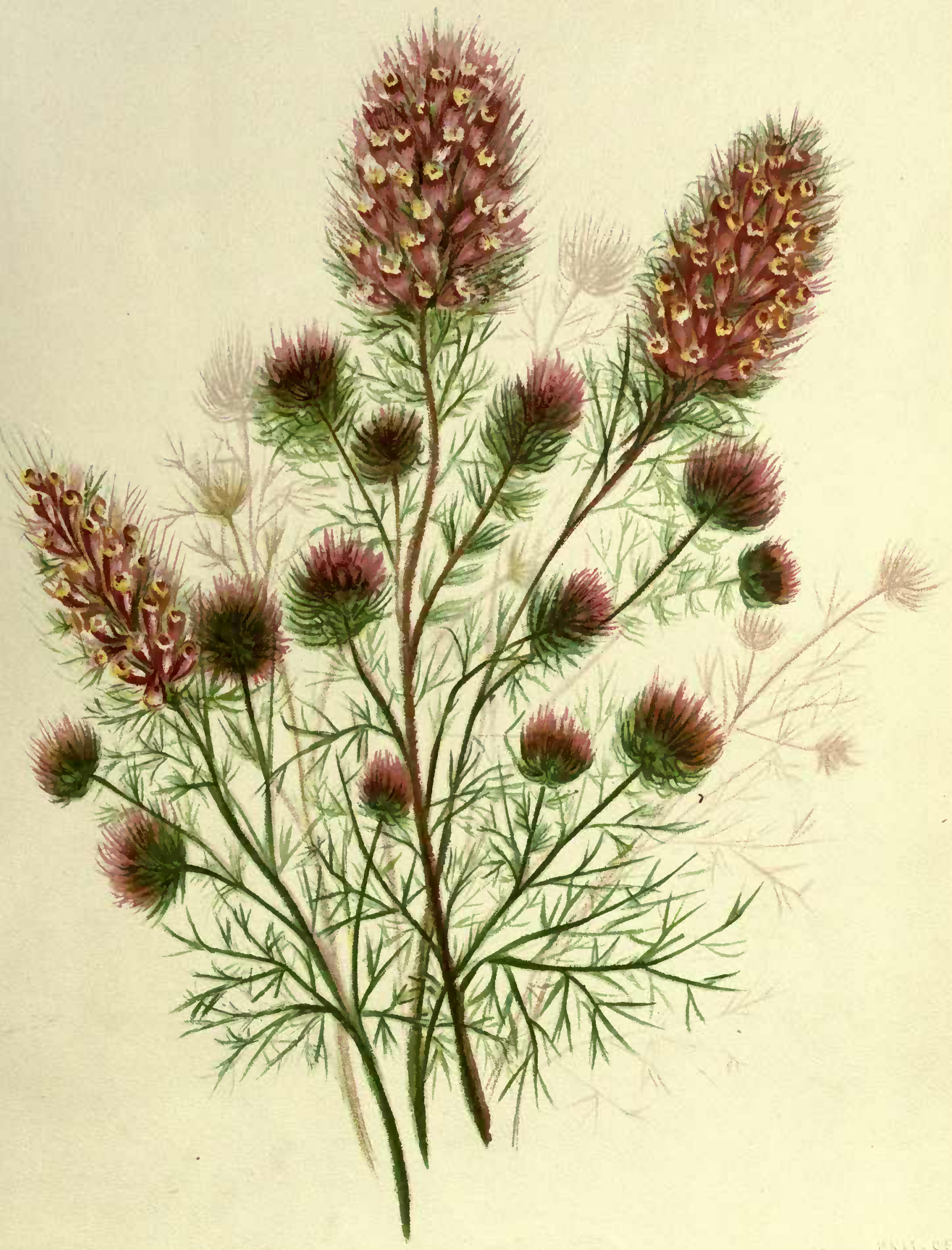





\section{BURR CLOVER.}

Is there any thing more lovely than youth? - a young girl just coming into womanhood? It is in California you find the loveliest girls in the world, large in stature and graceful in form. I have watched them by the hour, laughing and chatting, all unconscious of the great charm of their beauty-health.

There is something about the air of California that is exhilarating. It gives a kind of champagne pop to every thing. Men and women walk faster, ride faster, and live faster than in the East. Girls marry younger, and boys become men while yet in their teens. It is the climate.

Two young girls at my hotel interested me; they were great friends, and I found them well-informed and ever ready to give me information about their State, with a pride all possess who live in it.

I met them one day, their faces flushed and their hands full of great bunches of burr clover. "Where did you get them?" I asked. "They are beautiful." The flower was new to me, and consequently of great value. "At the mission "Dolores.' You can get just lovely ones there," they answered.

The next day found me at this wonderful mission, founded by the Spanish Friars in the year 1776 . The sexton points out the three little bells in the three square openings, and assures you they were brought from the Castle many years ago. The long narrow aisles lead you to the altar, and here we see what the 
sexton tells us is a painting of the Last Supper, the Madonna and the Christ, Saint Frances and Saint James. The walls, he tells us, are four feet thick, and they look fifty. A weak, closedin feeling comes over you, and you think of the lovely fresh air outside, and when you reach it, give a prayer of thanksgiving that you are allowed to breathe it again.

"Do you want to see the graveyard, miss?"

"Yes, if it is not under cover and the sunshine is allowed to come in," I answered.

"Plenty of sunshine there," and he leads the way.

As we pass through the gate the old man bows his head-so do I. We are in the presence of the dust of those that have slept here over a hundred years. We read the inscriptions and find them in six different languages-I should say see them in six-the hieroglyphics on the Indian headstones we could not decipher, but are assured they are the names of great chieftains.

On a board headstone, the lettering nearly washed out by the years of rain upon it, we see under the name the letters "V. C.," and ask what it means.

"Oh, that stands for Vigilance Committee; you will see that on some of the marble stones. Would I go further?"

"No, I had seen enough, if he would allow me to pick some of the burr clover growing near."

"Why, yes; take these growing near the slab of James Sullivan, the world-renowned 'Yankee Sullivan.' You see there is a 'V.C.' on it."

I took them, and so you see them in my sketch. 




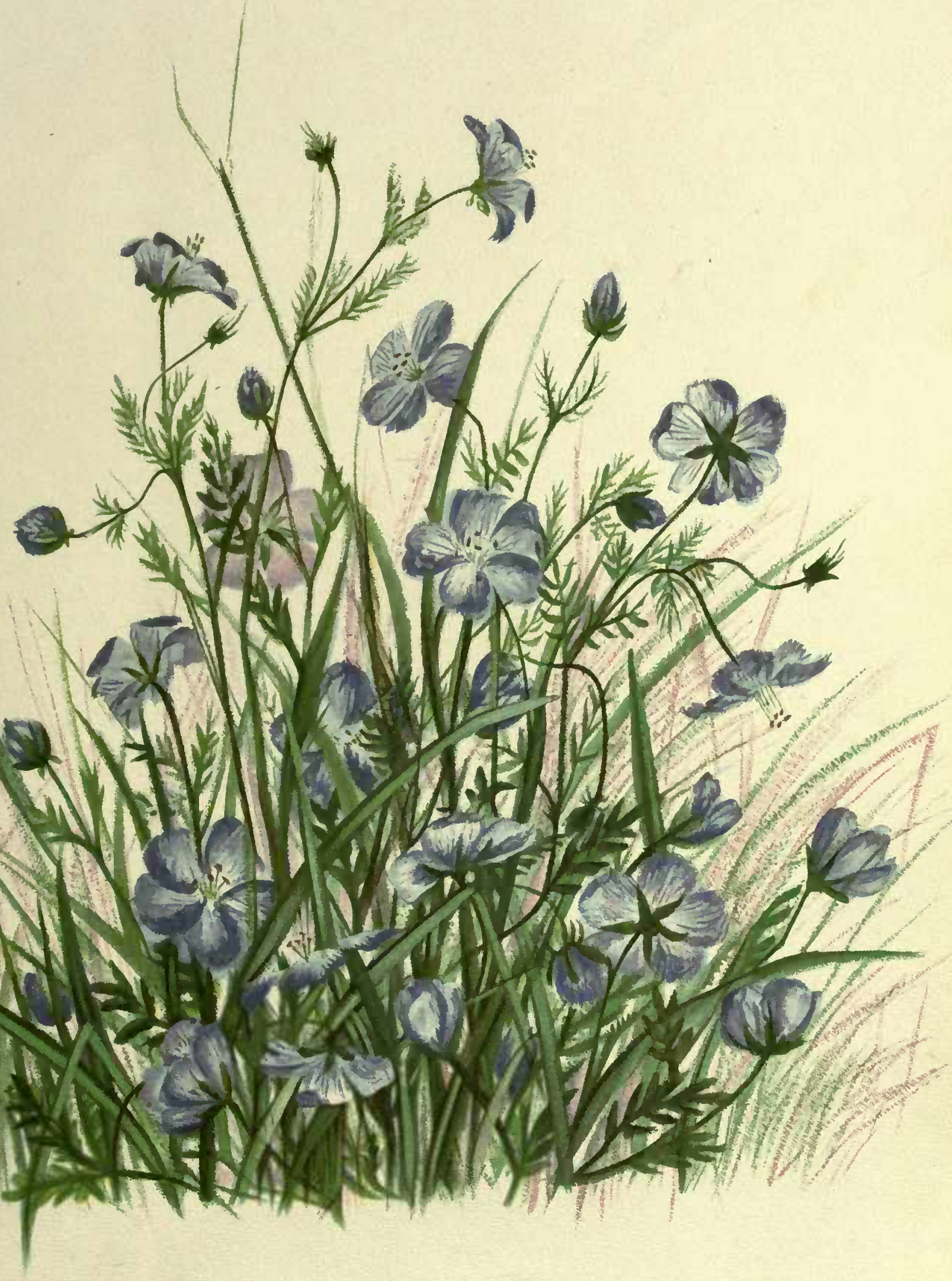





\section{BABY BLUE EYES.}

The name of "Monterey" has a charm for thousands of tourists who have visited that beautiful place, in the last three years. Indeed the interest in this place dates back to I 842, when the United States seized the territory of California, but relinquished. it the next day. Commodore Jones, of the American navy, captured the fort of Monterey, and hoisted the Stars and Stripes, but the next morning he hauled down his flag, and apologized for his mistake. They were not hoisted again until July 7 th, 1846 , and then by Commodore Sloat with no intention of imitating his predecessor's example by pulling them down.

"There is probably no place upon the coast so replete with natural charms as Monterey. Its exquisite beauty and variety of scenery is diversified with ocean, bay, lake and streamlet; mountain, hill and valley, and groves of oak, cypress, spruce, pine and other trees. The mountain views are very beautiful, particularly the Gabilan and Santa Cruz spurs."

In a beautiful park not far from the town of Monterey stands the magnificent hotel called "The Del Monte." "This is perfection, a-dream," said an enthusiastic girl standing near me, the morning after my arrival, and I could but echo her words. It was early, but the sun was far up, and its rays upon the freshly-watered grass threw countless diamonds on every blade.

The cultivated flowers were everywhere-in artistic clusters, 
the hand of an artist had arranged their start in life, and they had fully repaid him by arraying themselves in colors that perfectly blended with their neighbors.

The temptation to walk could not be resisted. As we turned the corner of the house, the odor of heliotrope was so strong it made us wonder if the gardener was using the perfume in his watering-pot. But we soon discovered from whence came the delicious odor. A vine completely covered the end of the hotel; it was up far above the second-story windows and thousands of blossoms were gracefully hanging from its branches.

As we continued our walk by the fountains and lakes we soon came to a grove of trees that had been left in their natural beauty. The grass was wild but smooth as velvet. On a little mound under a young bushy tree I saw what looked like a lightblue covering, and found peeping through the grass these pretty "blue babies'-eyes." They were so sweet, nestled away under this bush, too delicate and slender to bear the full rays of the sun, I could not pick them, but promised to spend the morning with them. Returning to the hotel for my colors, I took a hasty breakfast, and the rest of the morning found me seated by the side of these flowers so prettily named.

They are one of the favorites of the flora on the coast. All seem to love them. The prettiest decorations for a table I ever saw were sea-shells filled with these beautiful flowers.

A great variety of flowers grow around Monterey. The ladies bring in great bunches, making the "Del Monte" look like a conservatory of wild flowers. 


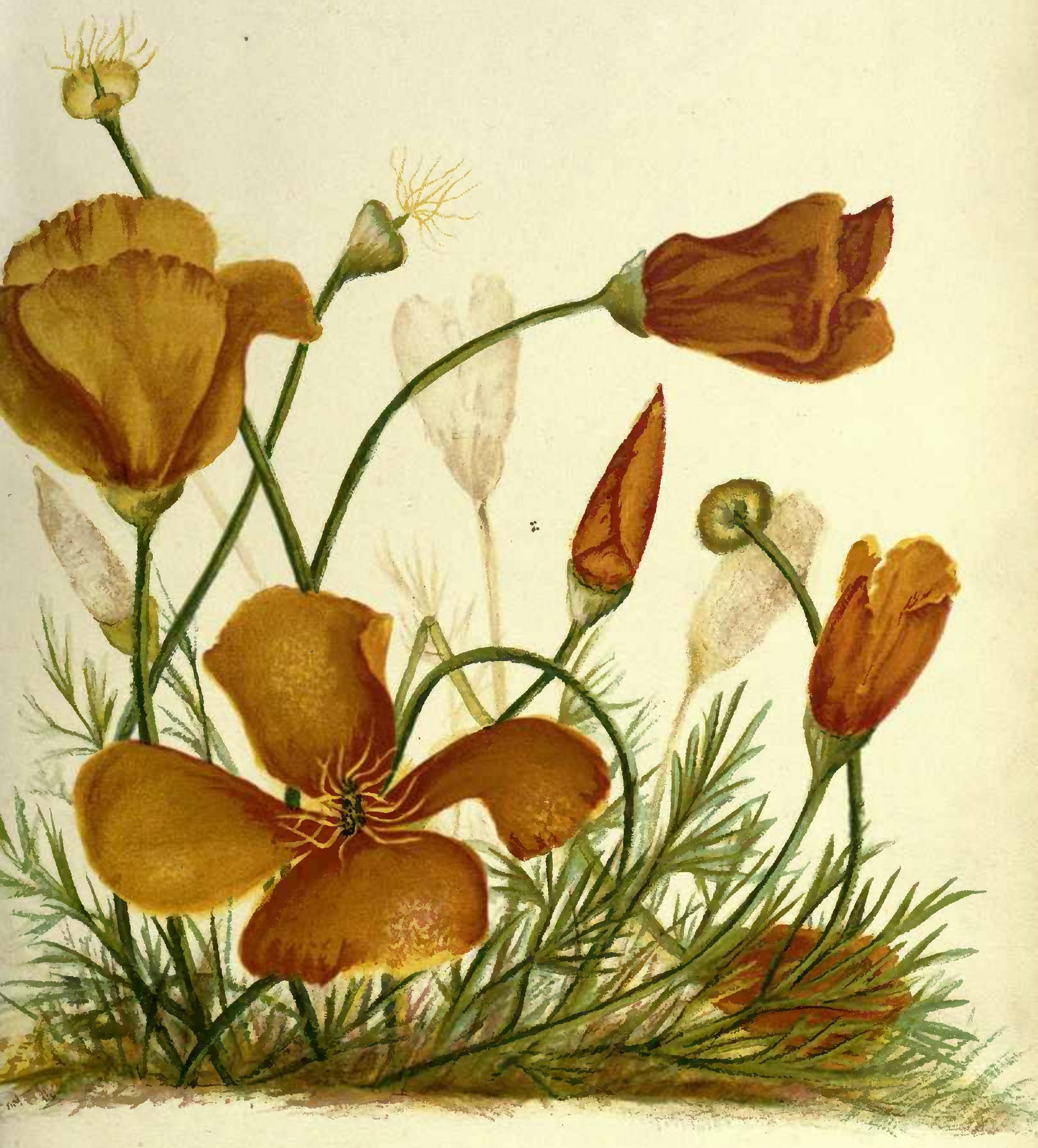





\section{YELLOW POPPY.}

On one of my trips over the Northern Pacific road, at a little station called "Santa Rosa," a man hurriedly entered the car, followed closely by his wife and little girl. Depositing the many bundles on the seat, he kissed them both and said, "There! Good-by! Take good care of yourselves and enjoy your trip." To the little girl he said, "Don't call me back or watch me out of sight, it's bad luck."

So simple and honest was this warning, I became interested in the man and watched him from the car window. Oh! no wonder he did not want them to watch him out of sight. The tears were falling fast as he unhitched his horses and jumped in the wagon and drove away, not once looking toward the car that held those most dear to him. What a sacrifice of feelings was this man making, and perhaps of his means also.

At this moment the train started. I felt so interested in this little family I offered some courtesy to the child, and soon had the mother in conversation. She had come to California when a young girl, with her father. Had married and settled on a ranch near Santa Rosa. Her husband, she said, had lived in the state nine years, and during that time they had married and had this one little girl. "He ain't been back once," she said, "although his mother writes constantly for him to come, and now since the tickets are so cheap, he insists on my going and taking daughter." 
"Too bad he could not go," I said.

"Yes, I just begged him to go, but 'twas no use. 'Mother has never seen you or Annie,' he said, 'and you can tell her all about how I look, and I can't leave the ranche; you must go.' I wonder if he's left the station?"

"Yes, I saw him get in his wagon and drive away."

"Oh! did you? How did he look? Poor Papa," and the child's eyes filled with tears.

I called her attention to some flowers along the road. She brightened up at once, and suddenly turning to me, asked, "Do you like wild flowers?"

"Yes, indeed I do ; do you?"

"I just love them. Mamma, where is my basket? Oh, here it is," and removing the paper she showed me some beautiful wild poppies. She had taken them with the earth about them so carefully, they looked as if they had not been disturbed.

"I am taking them to grandmother. Father said she was sure to like them."

"I know she will. Do you stop in San Francisco?" I inquired.

"Yes, one day, with a cousin," she answered.

I asked the privilege of keeping the flowers for the day. I wanted to paint them, because they were the finest I had ever seen, and as a remembrance of the little party I had met. As you look at them, you can think of the trip they took, and we may hope some of their descendants are now growing in the grandmother's garden. 


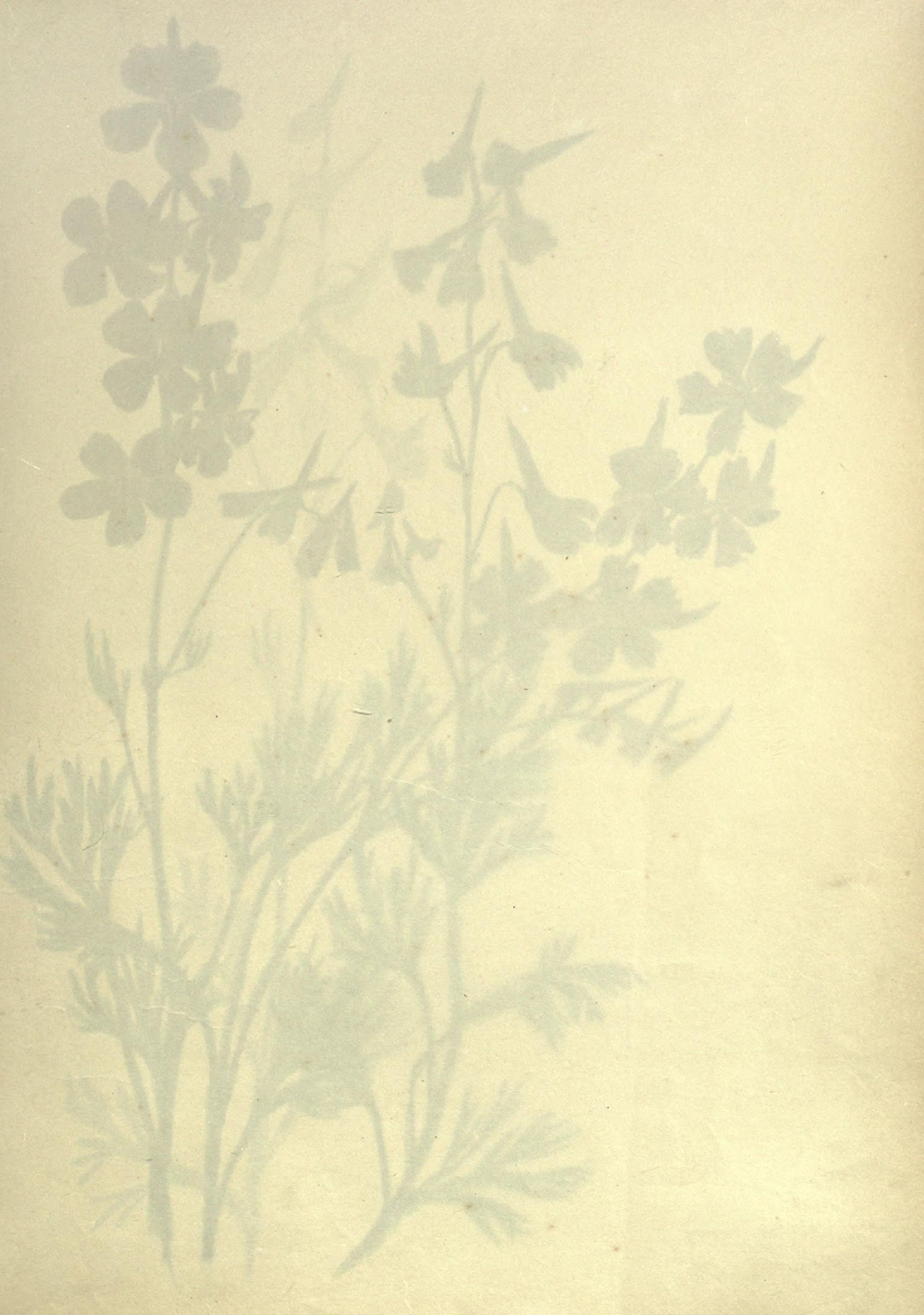





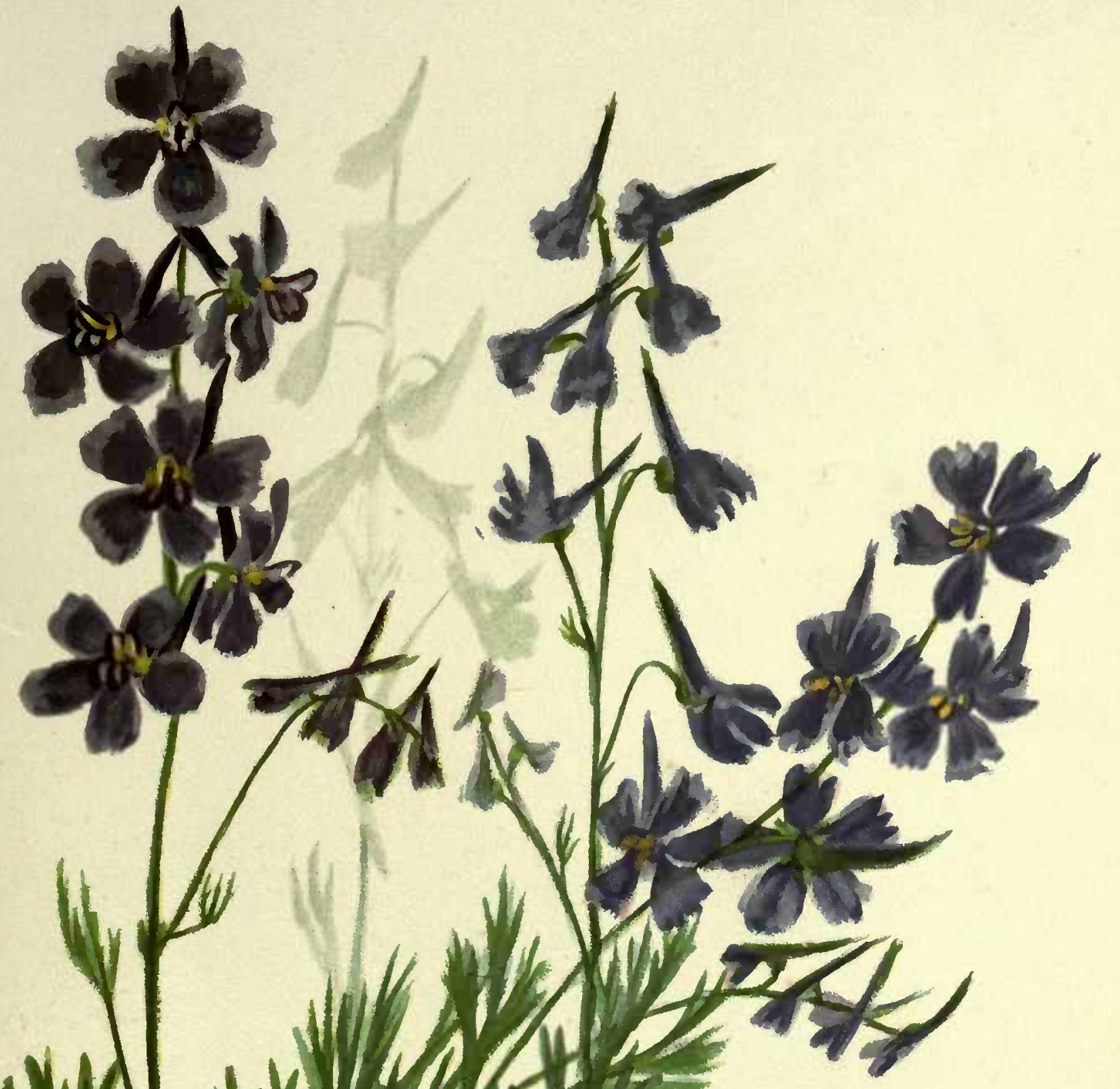

win wey

wad w
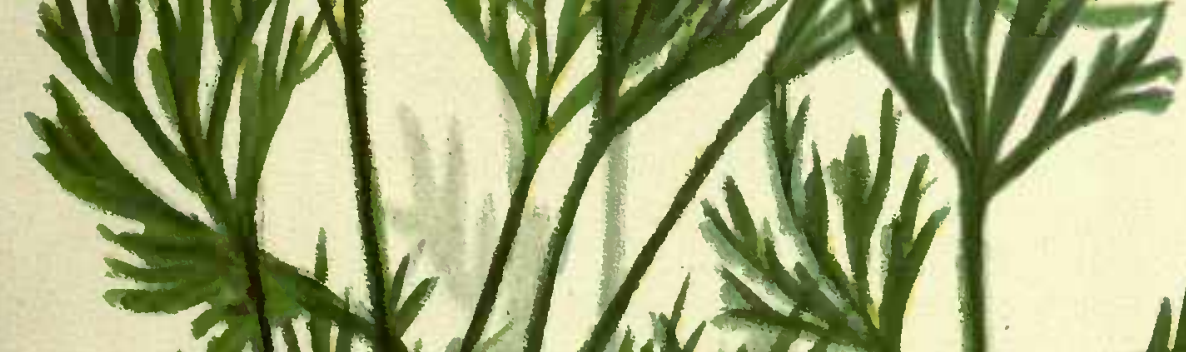
(iv) $x$ min (x)

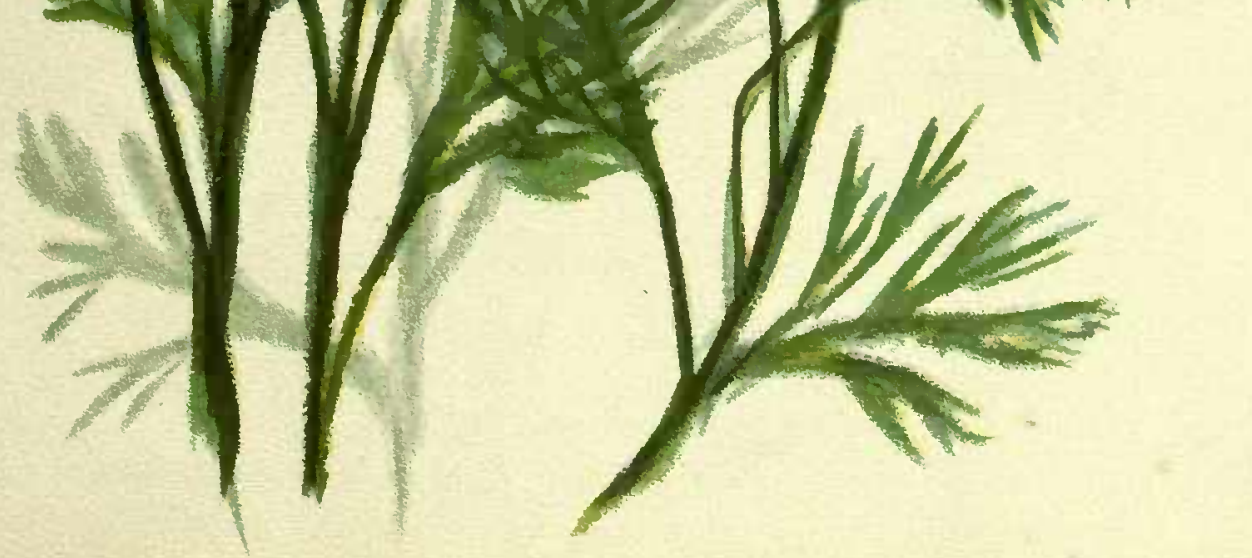





\section{LARKSPUR.}

I think one of the pleasantest short trips from San Francisco is the one to the Geysers. It was my pleasure to go on the beautiful narrow-gauge railroad as far as Clovedale. The rest of the trip was made by stages.

While waiting for the second coach I looked at the little town and thought its situation very beautiful. So pleased was I with it I forgot to demand, as my companions had done, the "best seat."

"Well, ma'am, will you take this seat? It ain't no ways pleasant, but as you ain't said nothing about no seat, maybe you're not particular."

I looked up and saw a small space left between two women whose weight had already tested the springs, and being neither thin nor delicate myself, I hesitated.

"It'll be awful hot," said one of the women.

"And dusty," said the second.

"Yes, and crowded," said I.

"If you ain't pressed for time I'd wait and engage the front seat on to-morrow's coach," said the polite agent standing near me.

"I will be glad to do so," I said, much relieved, for the very thought of crowding in a seat between two women had made me feel warm and fatigued.

We reached Clovedale (which is so prettily and appropriately named) about noon. After a good luncheon, I walked 
out to the suburbs of the town and followed a path which led me to the top of a hill. As I walked, the pink clover in full bloom sent forth a lovely odor.

On this hill, and on this quiet afternoon, I found the larkspur growing. Its colors looked richer against the background of clear blue sky, and I thought it worthy of being sketched.

I could imagine Clovedale a New England town from the flora I found there. The columbine, small, red and growing on - slender stems, grows here as it does in our eastern woods. The flag lily, purple, lavender and white, I found in abundance. Even the clover had an eastern look, and it would seem as if the flowers had formed a colony, and chosen this beautiful spot as their future home.

The next day, found me in the "front seat," by the side of the driver. It was mine by right of engagement, much to the annoyance of the six fellow-passengers, all of whom, with pockets well stocked with cigars, to bribe the driver, expected to take it.

"I think you will find this seat much pleasanter, and I hope you are not sorry you staid over, miss," said the kindhearted agent.

"Sorry? Oh no, I am glad that circumstances detained me here. I shall always associate it with clover-blossoms, no matter when or where I see them growing."

Crack! went the whip, the "leaders" gave a spring, and Clovedale, with its quiet homes, its honey-laden bees, and flowers, left behind us. 




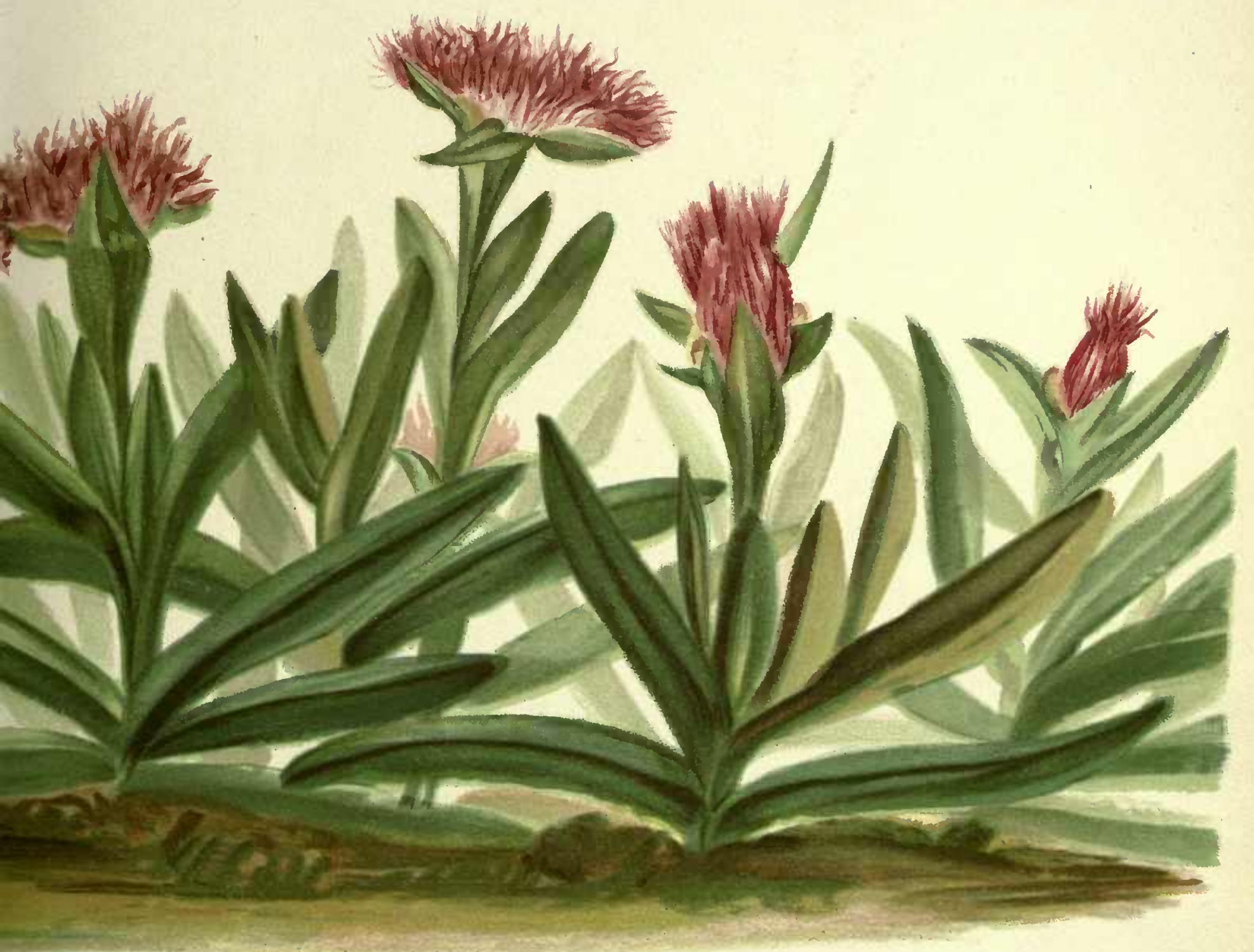





\section{WILD THRIFT.}

Will you go to the shore and take a bath? is almost the first question asked you after reaching Santa Cruz. It was a pleasing question to me and I quickly answered, "Yes, as soon as I have had luncheon."

"Cars run right by the door, miss, every fifteen minutes, take you plumb up to the door of the baths, and you can stay as long as you like for the same price."

The day, being the latter part of Marcli, was a little. cool, but the salt water in my bath was warm and delicious; yes, delicious. I know no other word that so well expresses a warm salt water bath after days of hot dusty travel.

As I walked along on the warm sand, thoroughly refreshed by my bath, with no particular aim in view, I came suddenly upon some writing with a ring drawn around it.

I looked closely and read, "Go straight ahead fifty-seven steps, then turn to the right thirty-three steps, and you will see a mighty pretty flower." I read it the second time. Surely it had not been long written; it looked as if freshly done in the yet damp sand. I had seen no one on the beach, and looked around to find the writer. In looking back I saw I had unconsciously turned a point on the beach, and the writer, whoever it had been, was out of sight. I read again, and then saw for the first time foot-prints, so small they must be of a child, and the toes pointed toward the cliff. I followed the foot-prints and 
came to an old deserted boat that was lying close up under the bank, and behind it and just above the top, I saw a pair of darkbrown eyes.

"Did you write that for me?" I asked.

"Yes, mum," and the bright eyes twinkled.

"How did you know I was looking for flowers?"

"Oh, I heard you ask at the hotel if there were any wild flowers growing on the beach, and I just knew there was, and I run ahead to let you know."

"You are very good," I said. "Come out and let me see you, and if you will go with me I shall be glad to see the flowers." She stood up and I found her to be a young girl about eleven years old, and the daughter of a fisherman living near the beach. She was a bright interesting little thing, and loved flowers. She gave me much information as we walked along, and when we reached this patch of wild thrift, I was informed that it was "the only lot that had blossomed this spring."

As I made my sketch she chatted, and often the little face with the pretty brown eyes would get between my brush and the blossoms I was sketching.

"I would just like some paints like yours. I'd paint every flower as fast as they came out, if I had the paints."

"You shall have a box for your kindness," I said, "and a lesson also, if you will come to the hotel with me." She was the happiest child that night in Santa Cruz. I believe she will, some day, be a fine artist, as she showed wonderful talent in one so young. 






\section{CLUSTER LILY.}

These lilies I think much handsomer growing than in the sketch. As we find them standing erect on their delicate stems, each lily so perfect in the cluster, we are ready to say no brush can do them justice.

Like the poppy, they grow in patches, and instead of the yellow carpet, we find the purple, lavender and delicate blue, but rarely the pink.

I found these little flowers a great favorite with the young ladies. They can choose from the color most becoming, and wear them for a whole evening without losing their freshness.

I found the most perfect of these lilies in the Napa. Valley. This lovely valley seems to be the home of the wild flowers: every variety found in the state grows here, and the growth is rich in size and color.

Napa Valley is better known to eastern people than any other in the state. It has gained a reputation for richness of soil and beautiful vineyards that make all tourists wish to visit it.

I found all of the valleys equally inviting. No matter in which direction you may go, on any of the railroads, you are sure to find yourself in one of these lovely valleys, with ranches here and there, and every few miles a pretty village with its church steeples rising high in the air, surmounted with little brass crosses and weather-cocks, that send the sun's rays far down the valley, as if to guide the weary traveler home. 
It was in the San Joaquin and Sacramento Valleys I found the greatest variety of birds. I saw here a fine species of the road-runner, which is much like the cuckoo; but in habits more like the pheasant in running, and its inability to fly.

Perhaps the most interesting of all birds is the California wood-pecker (Melanerpes formicivorus), which has the curious habit of boring holes in the bark of trees and filling them with acorns, which fit most accurately and closely in the cavities thus made. The object of this arrangement appears to be to allow the grubs to fatten inside the acorns, which thus in time are found to contain a nice meal for the provident bird.

The quail of California are very handsome. There are two species, and both have elegant crests of long narrow feathers. In one species they turn backward, in the other forward. They are taller and more slender than the quail of the Eastern States. I am not a sportswoman, but I have killed my quail. Once when a child, with a horse-hair noose set as a trap, many of them on a string stretched tight and fastened to little sticks, underneath which grains of wheat were scattered to entice the innocent bird to hang himself. And again while in Sacramento Valley with a party of friends, one of whom handed me a little shot-gun and said, "Point the sight at that bush; now, fire." I did so, and a family of quail scattcred, leaving behind them a son. His crest turned backward, and he now stands on a miniature stump which adorns the most attractive corner of my cabinet. 


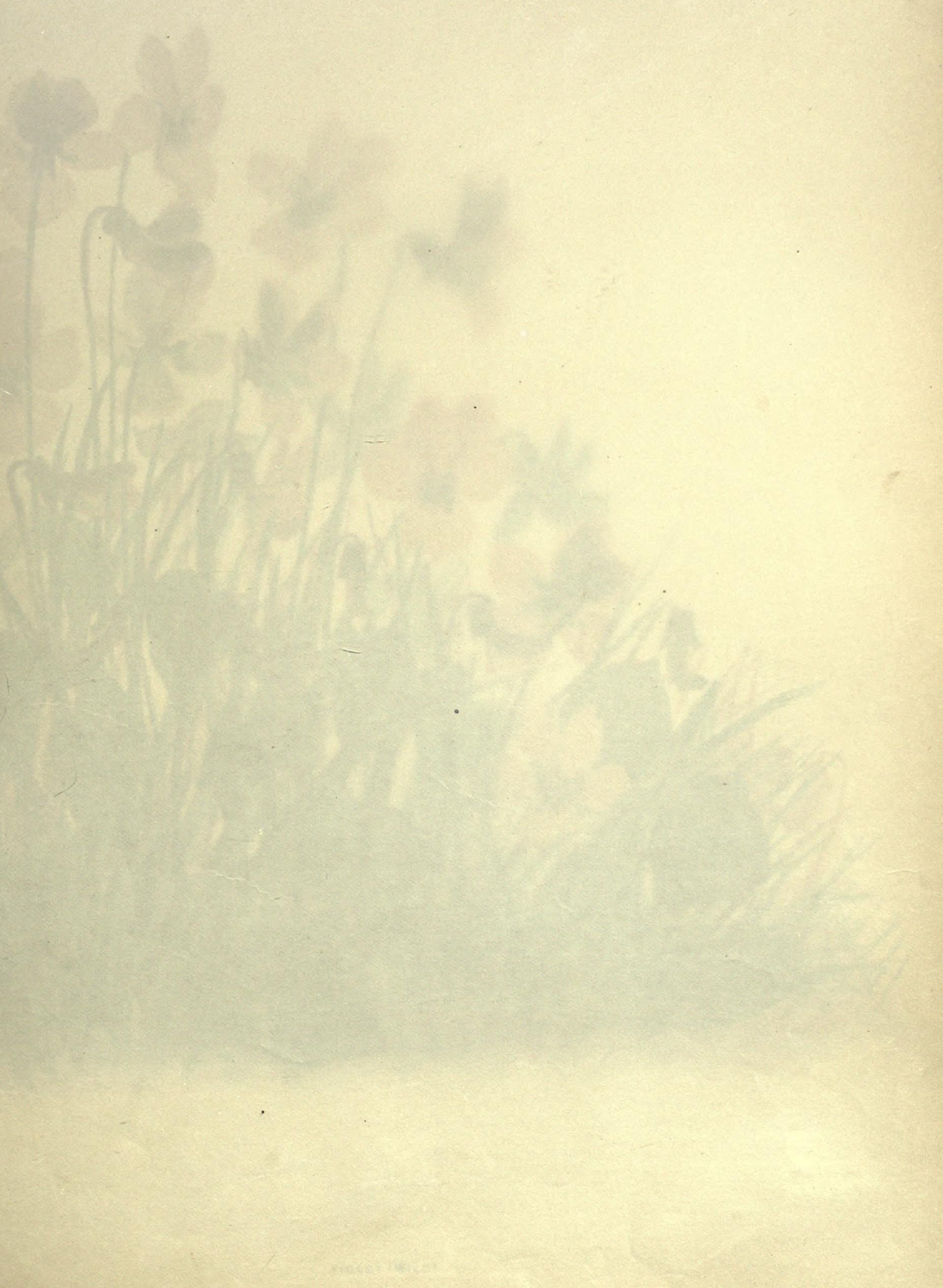





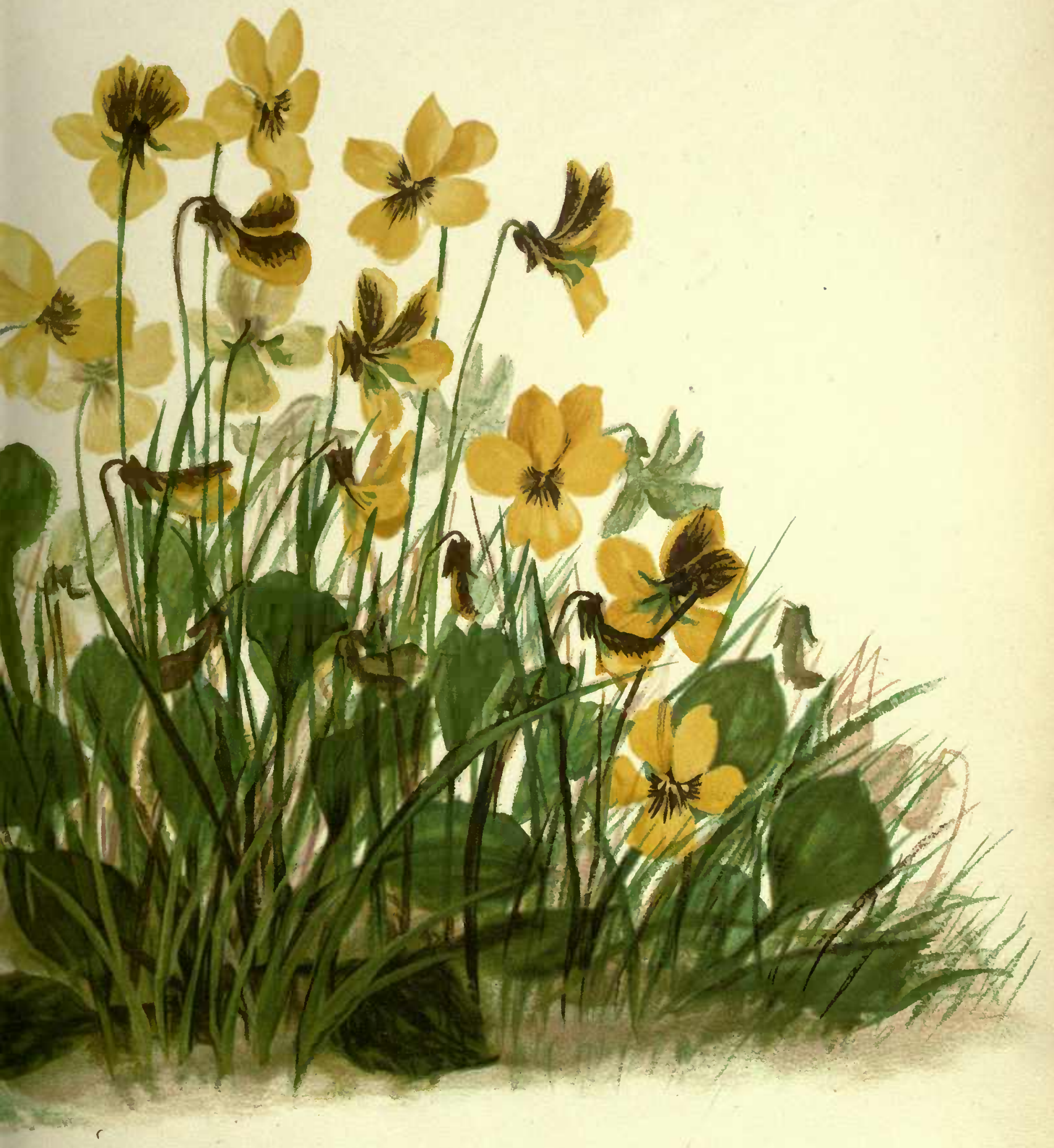





\section{VIOLET.}

Have you ever visited San Jose? If you have you know much better than I can tell you of its beauties. No description of a place can equal a visit. We may read of cities and beautiful countries, and get some idea of them, but a visit is never forgotten; if pleasant, the memory remains through life.

San Jose is situated in the heart of the lovely valley of SantaClara. On the east are the Coast Range of mountains, and on the west the Santa-Clara range. This charming place is called the Garden City of California, and the New Haven of the Pacific.

Its wealth of trees, flowers and shrubbery, and the multifarious adornments of nature and art, make it one of the popular cities of the Coast.

Almond Rock is one of the points of interest, and the drive there the finest in the place. It was on this drive I first saw the violet, so called by the people of California, but so much resembling the pansy of the east, it was difficult for me not to call it by that pretty name given to its sister.

These in my sketch were growing in a pasture in which cows were feeding. With their bright-colored faces turned to the sun they covered nearly half an acre of ground. I selected this bunch, carefully removing the earth with them, much to the consternation of the cows, who drew near with curiosity, wondering, no doubt, why I was disturbing their pretty garden.

It was in San Jose I saw such beautifully cultivated gardens. 
Blossoms of all kinds grow to an immense size. The roses were here in abundance, and so large and fine I begged some to send to an Eastern friend, who thought her roses the finest in the country. She wrote me "You intended this box of lovely roses as a pleasure to me I am quite sure, but they have brought with them a desire so great to visit the land that produces such marvelous flowers, I fear I shall not be contented or entirely happy until I have seen them growing in their native soil."

Hedges of callas and geraniums are common here, and the heliotrope is trained as we would train the honeysuckle vine in the East.

I saw some fine groves of apricots and olives growing, and the English walnut is extensively cultivated. The friends who entertained me while at San Jose raised their own English walnuts, and cured and prepared their raisins.

I became interested in the curing of raisins while in California. Much attention is being given to it. They have two methods of preparing them. One method consists in partially cutting through the stalk of the ripened bunches of grapes and allowing them to shrink and dry upon the vines by the heat of the sun. By the other method they are gathered and hung on lines, or laid on prepared floors to dry in the sun. When dried they are dipped in a hot lye, to which is added olive oil and a little salt. After dipping, the fruit is laid on hurdles of wickerwork to drain, and is constantly exposed to the sun for about a fortnight. The raisins are then pulled from the stalk and packed into boxes ready for the eastern markets. 




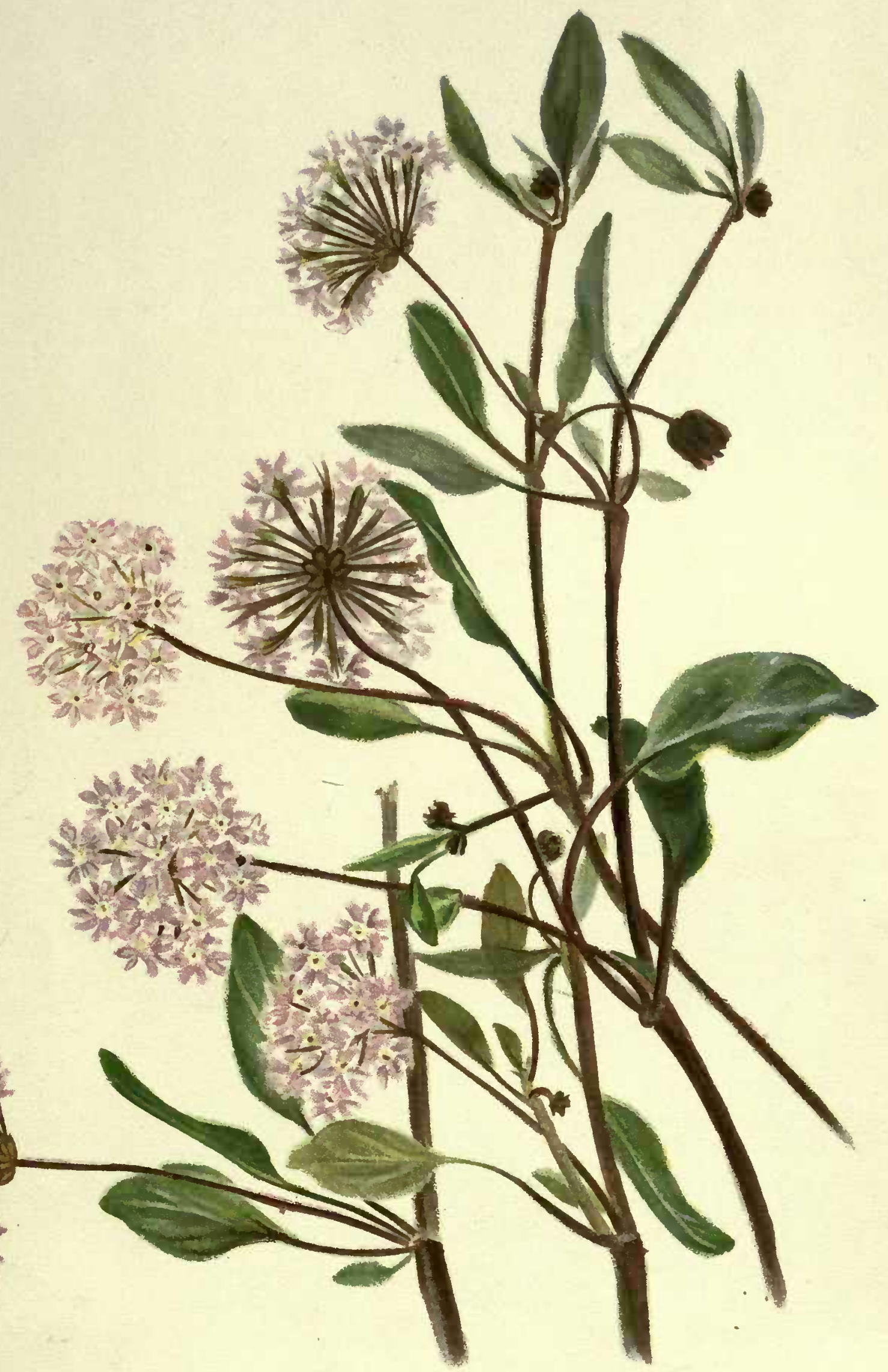





\section{WILD VERBENA.}

From Los Angeles to Long Beach is two-thirds of a day's travel; at least it was when I visited the place-by this time the railroad is finished through to the Beach, I am quite sure. It has a lovely beach and is a place that has much promise. It will attract the better class wishing quiet and good bathing. I am told, in the extreme hot season families take their tents and pitch them in some nice sheltered place on the beach and remain there for many weeks.

At this place I found under peculiar circumstances the wild verbena. I had started out quite early in the morning, having been directed where I would be likely to find it growing. I had heard much of the plant, and came here purposely to make a study of it.

I had walked what seemed to me a mile or more along the beach, and not finding the flower I so much desired, had turned back quite discouraged. I had gone but a short distance when a dog came leaping over the embankment and ran to me, much to my alarm; but I soon discovered that he meant only kindness. He would run ahead, then wait until I came up to him; sometimes he would return and leap and jump about me and then run on ahead again. He kept on in this way for quite a half hour, when, nearing a grove of trees a short distance ahead, he ran toward them. I thought he had decicled to leave me, and so walked on, but in a moment he came barking toward me. I 
patted him on the head and he again turned toward the trees. I stood still, and when he turned and saw me standing, he howled most piteously. I went toward him. He immediately went on, turning every instant to look at me. I could not understand the dog, but followed him. When he saw me coming he commenced his old playful manner. Suddenly he stopped and lay down. Directly in front of him I saw a beautiful vine of wild verbena.

I can not tell you my astonishment. I looked at the verbena, then at the dog, who had stretched himself out as if intending to remain. I seated myself beside him, and the three hours I spent in making my painting of this, the finest specimen I have ever seen of wild verbena, the faithful animal never left me, but remained quiet, sometimes asleep, sometimes looking at my hand as it applied the colors.

When finished he came with me to the hotel. I went to the office to inquire if any one knew the dog; when they came out to look at him he had gone.

I walked again on the beach the next morning, in hopes of seeing my kind companion of the day before, but he did not come. I went to the place I had first seen him and called, but he was not to be seen. I inquired of some small boys. who I felt sure would know him from my description. No, they never "See no such cur." "He is not a cur," I answered, "but a beautiful, intelligent dog." "Well, maybe he be, but we ain't seen him."

It was with much regret I left Long Beach without again seeing the best friend I met while there. 


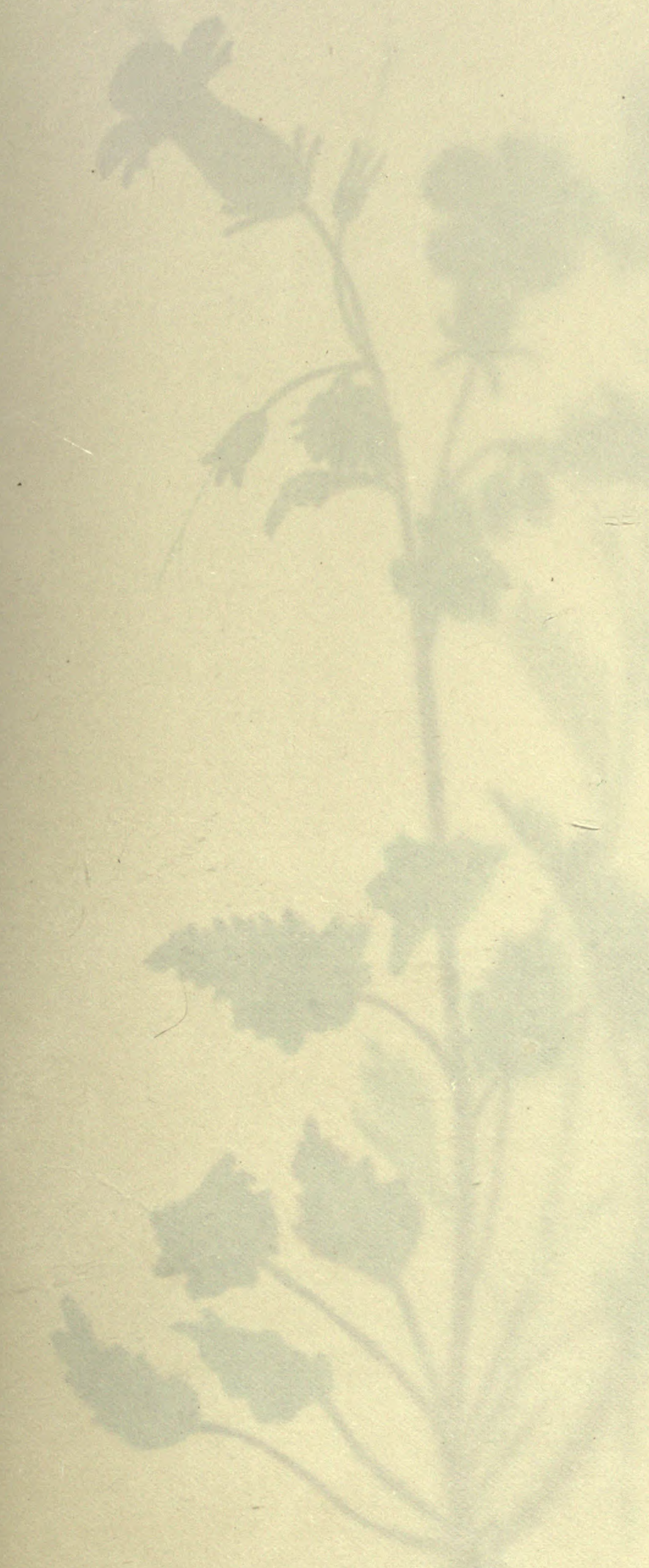





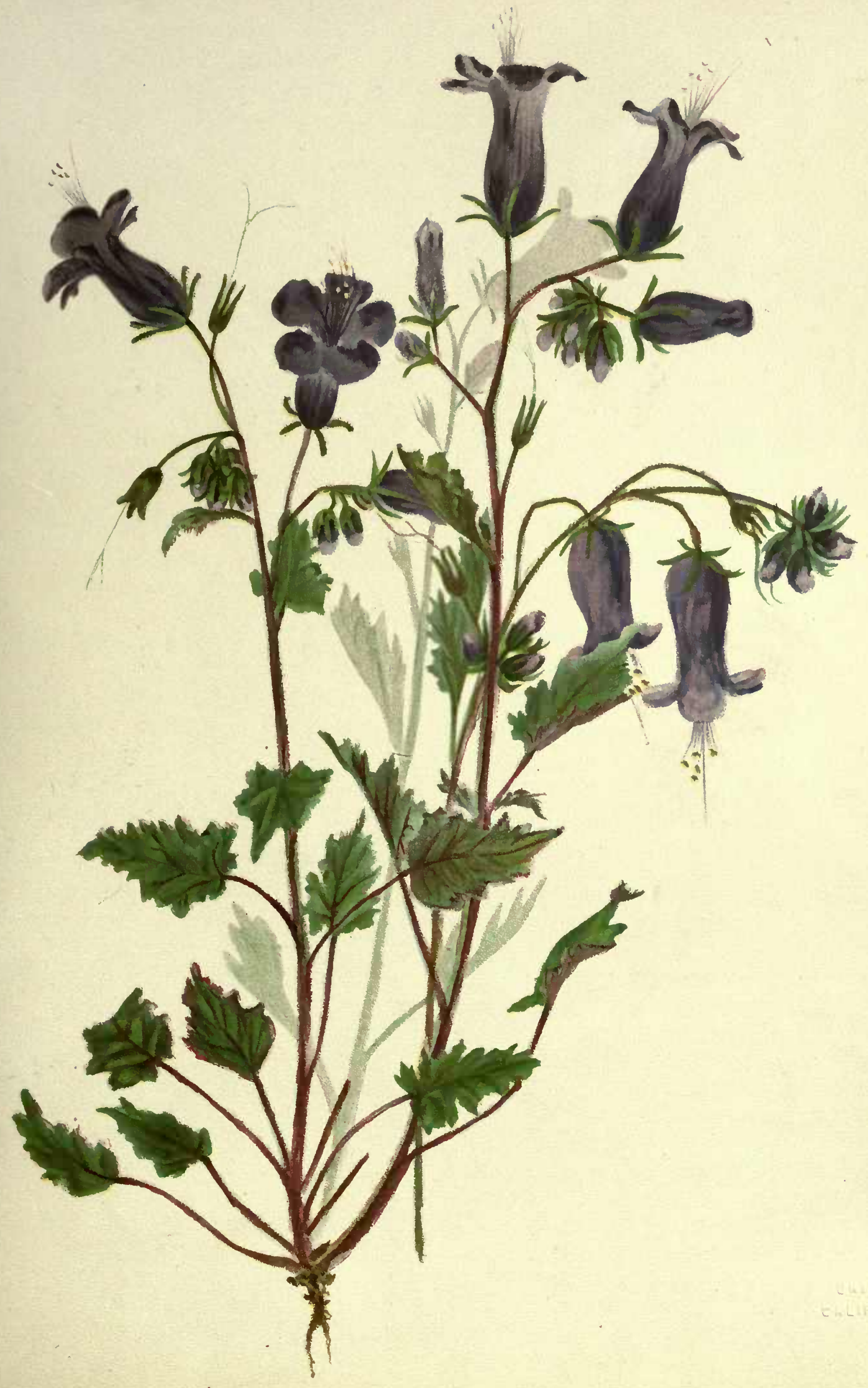





\section{BLUE BELLS.}

On one of my trips out of San Francisco I visited a pretty town called San Rafael. I should say I started to visit it. In the same car with me I noticed a little boy, whose face had such an anxious look I became interested in him. A woman sat beside him, and on her face he seemed to constantly keep his eyes.

As we neared the town he said, "Now this is San Rafael. Let us get out." And picking up his bag he stood ready. The woman did not move but said :

"Keep your seat, we go further."

"You told me we were coming here."

No answer from the woman.

"Where are you going to take me?" and the tears that had been ready all along sprang out, while the boy continued to look in the woman's face, the muscles of which never moved.

The train started. "Where are you going?" He did not say mother, neither did he address her by name, but he had such a thin little face, and such great sad eyes, my heart went out to the little fellow, and so interested had I become in him, I had forgotten to get off at San Rafael, and found myself carried along I knew not where.

We had gone quite a distance when the woman looked out of the window on my side of the car. The boy followed the look, so did I, and saw a huge pile of buildings, on the top of 
which a wooden cross stood out plain and clear against the sky.

"You're not going to take me there?" cried the boy, and his little hands clutched her arm.

By this time we reached the platform, and the huge buildings under the cross were before us. The woman picked up the bag, and taking the child by the arm they got off the train. I followed. Neither the woman nor the boy seemed to notice me. He, poor child, saw nothing but the woman's face and the buildings.

A path led up to the entrance of the inclosure, and the woman, taking the child by the hand, walked rapidly ahead.

"Oh! what have I done? Please don't take me there," I heard the child saying, but the woman -never spoke, but walked quickly on. As she reached the gate it opened as if by magic, and the two disappeared behind it.

I stood in the path with an ache in my heart for the child behind the gate, who did not know "what he had done," or "why he was taken there."

My situation was rather ludicrous. I stood there alone, not a person to be seen. I walked back to the little platform and saw on a poster that the train would not return in six hours. Green fields were all about me, and in the distance a piece of woods that looked cool and inviting.

I walked over to them and found these pretty blue flowers, with the dew still upon them. As I sketched them the dew disappeared, and so, we will hope, the tears did from the face of the dear little child. 




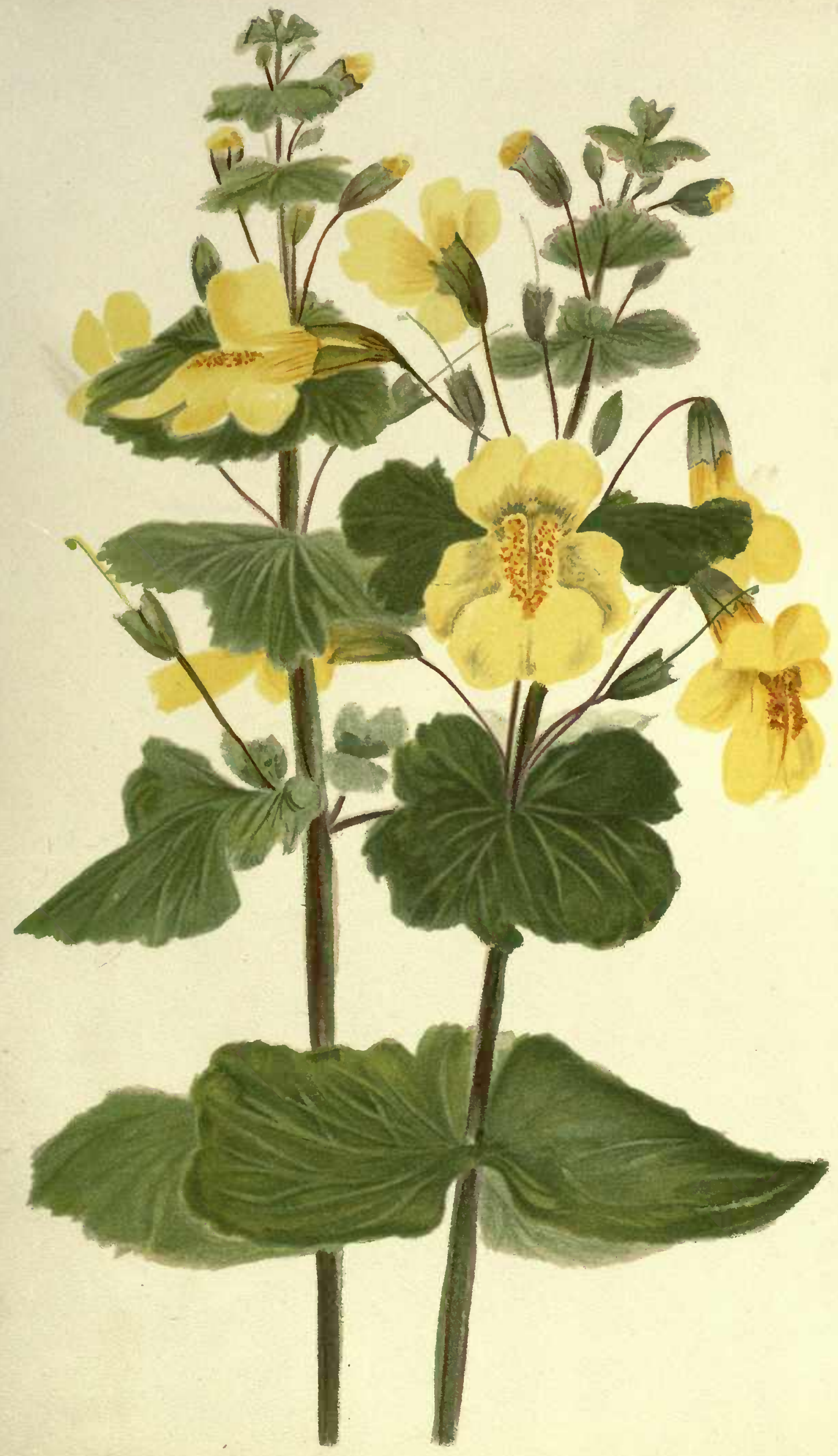





\section{SNAP-DRAGON.}

The Sierra Nevada mountains of California are the largest and most interesting chain of mountains in the United States. The range, starting from Mt. St. Bernardino, is about four hundred miles long, its peaks in places towering high above the snow line, Mt. Whitney being about six hundred feet higher than any peak yet measured in the Rocky Mountains. All of the very high peaks of the Sierra are of granite. In the northern part there are peaks of metamorphic rock, and many of the summits show volcanic materials. Lassen Peak, io,577 feet, and Mount Shasta, 14,440 feet (above the sea), are extinct volcanoes.

Like an emerald ring encircling this huge finger, are rich ranches to be found at its base, and far up the sides of the mountains. It was my good fortune to be entertained at one of these delightful places. While there, I had for my particular use a fine saddle-horse, and his constant companion was a dog that belonged to no particular breed, and made up in faithfulness what he lacked in beauty.

One morning after an hour's ride I dismounted by a lovely bed of moss, and having ticd the horse to a young branch, I was soon interested in examining the cells and delicate colorings of the moss through a small magnifying-glass.

The loud barking of the dog attracted my attention, and I looked up, to discover the horse quietly walking up the side of the mountain, nipping the young lcaves as. he passed along. 
I called whoa! He paid not the least attention to me, but walked, as I thought, a little faster. I quickened my pace; so did he. He kept close to the side of the mountain; so did I; for the path grew narrower and more difficult. The space between us widened as we ascended. Turning a sharp angle I saw a small clearing and a house artistically built of logs against the side of the mountain. I stood still, both from surprise and fatigue, and saw the horse walk straight up to the door. The door opened; a man came out. He patted the horse, and that miserable animal that had not allowed me to get within reach of his head, actually laid it upon the man's shoulder as if caressing him.

Hot, dusty, my face red, and dress torn, I stood hesitating what to do. The dog decided for me. He gave a loud bark and ran forward. The man looked toward the dog and discovered me. He raised his hat and came forward, saying, "I fear Dick has given you a hard chase. I have owned that horse for six years, and only last spring sold him to the people on the ranche below. This is the first chance he has had to run home, and I am glad to see him. Will you come in?"

"If this is his old home I will stay long enough to give him a little visit," I said.

Inside the log house I found the man's wife, a woman of rare intelligence, who spent much time each day in collecting and pressing wild flowers. It was near their place I found this snapdragon. It grew in great abundance here, and I chose it as the finest of the flora seen during my stay in the ranche in the Sierra Nevada mountains. 





\section{SHOOTING STAR.}

This pretty cluster of stately little flowers came from River Side, and reminds me of lovely homes, orange groves, and beautiful gardens of cultivated flowers.

Of all the wild flowers I found here I thought the shooting star the finest. It grows in a modest sort of way, a little bush here and there, shooting straight up as if to hold its head above its neighbors before uncovering the handsome face to the gaze of its companions, and then blushes and looks down, never again daring to raise its pretty face. One of the blossoms of this pretty bunch I saw open. It was early morning, and when I made my sketch a fine large bud was the first "laid on," and when I had quickly sketched the others and was about to finish the bud, I thought it moved. I looked closely and saw one of the leaves slowly unfold, then another quietly spread out its lavender loveliness, and soon the bud I had carefully sketched in stood before me a full-blown flower.

With this flower I associate one of the finest orange groves it was my pleasure to visit while on the coast. I had finished my work and was starting back to my hotel, when I met a little boy - a manly little fellow about four years old. He was walking in the center of the road, and with each step a little cloud of dust followed him. He seemed so interested in these little whirlwinds he did not notice me until I spoke to him.

"Where are you going, my little man?" 
"I's doing home," with a vigorous kick at the dust.

"Where is your home, little boy?"

"In heben," he answered.

I was amused by his answer, and leading him by the hand to a large stone by the roadside, I sat down and questioned him. I found out the little fellow was lost. He did not know in which direction was his home, as he said all of them were right. $\mathrm{He}$ wanted to sit on my lap. I took him up, and in a few moments the tired little fellow lay in my arms, asleep.

The situation was growing interesting. There I sat on the highway with a strange little boy in my arms sound asleep. I was wondering what I should do with him, when a carriage drawn by foaming horses came dashing down the road. As they came near me, I heard a scream, so sudden and painful I nearly dropped the child from my lap from fright. The horses stopped, a woman jumped out, and running toward me, she called, "Oh, Richie, darling, has mamma found you?" and almost snatched the boy from my arms. If she was glad to find her child, I was more than pleased to have him found. Gathering up my sketches, I was about to "move on," when the mother rushed at me.

"Oh, tell me, where did you find my darling? I have been nearly wild!" I explained, and then she discovered the sketches in my hand. Soon we were very good friends. It ended in my driving with them to their home in one of those beautiful groves of orange trees, from the odor of which one could imagine the procession of a thousand brides passing. 




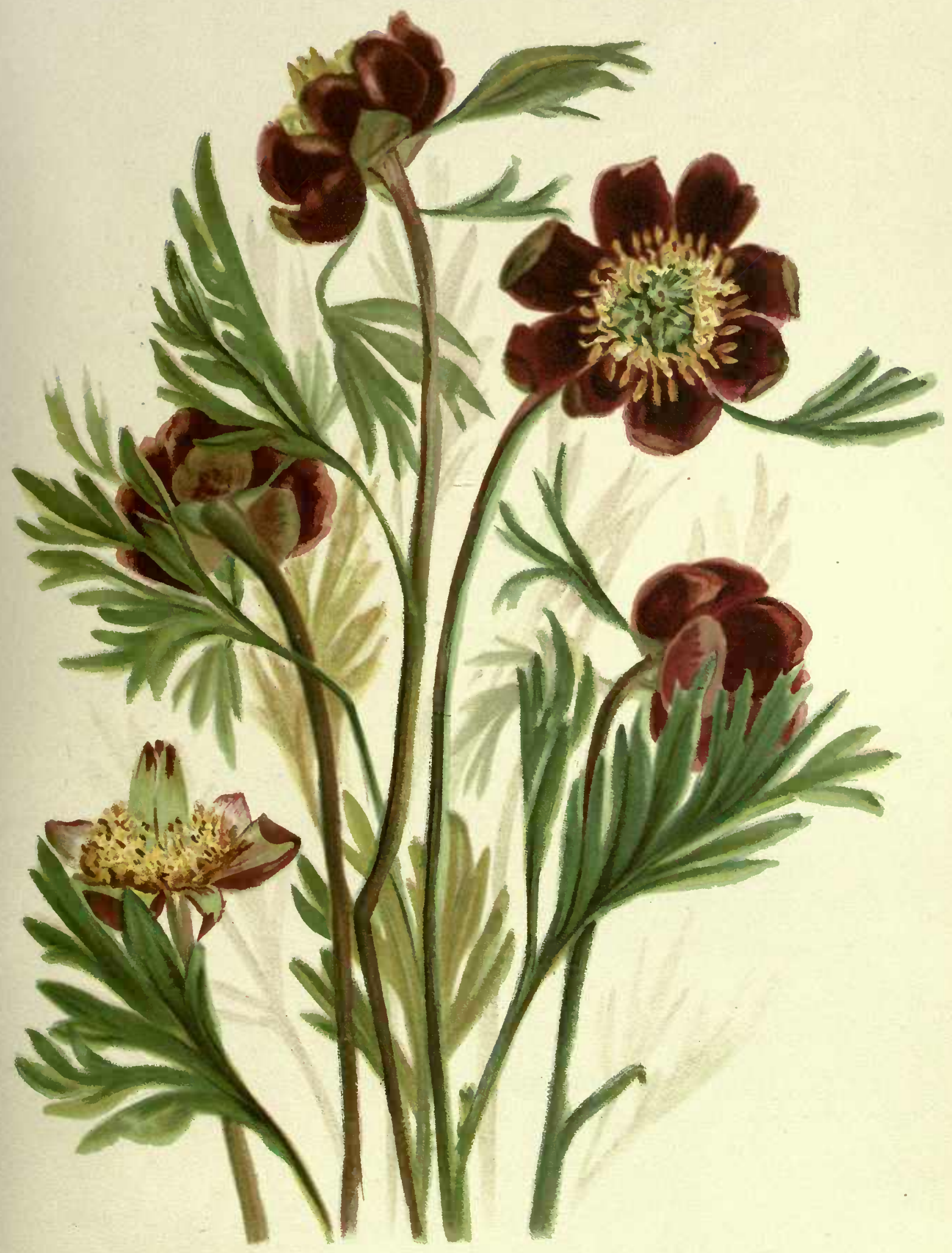





\section{WILD PEONY.}

Southern California has many beautiful towns; one of them is Pasadina. Its fine situation, even and delightful climate, make it one of the favorite resorts for both winter and summer.

It is in this lovely place the celebrated Raymond Hotel is situated. In the distance can be seen "Old Baldy" covered with snow, and nearer the magnificent range of the Sierra Madre mountains. Below, and at the very foot-hills, fine ranches can be easily traced by their rich fields of growing grain, and here and there the golden poppy claims the ground, and looks like a bright yellow carpet. So vivid is its color that patches of them can be seen for miles.

It was my good fortune to be entertained, while stopping in this charming place, by a lady whose home was on the ridge, and in the midst of a fine orange grove. On the trees could be seen oranges, ripe and green, and orange blossoms. It seemed so strange to me to see the blossoms on the same tree with the ripe fruit. The odor from this grove of orange trees was delicious. The early morning was to me the pleasantest part of the day. I was assigned the task of picking the oranges for breakfast, after being taught to know the full ripe ones, which I assure you is a great knowledge.

The pretty little cottage was nearly covered with rose-vines. They ran far up on the roof, and were just coming into blossom. The place seemed like fairy-land. Who could not be happy in 
such a home with such surroundings? Just back of the house was the "Arroyo," and I was told it was a perfect garden of wild flowers. A path well trod by lovers of Nature led me down to the very bed of the river.

It was here I found the peony, a bush here and there, the branches lying on the ground. In growth they resemble the cultivated peony; the flower, as you see, being much smaller, but extremely rich in color.

There is something about the blossom of the wild peony that reminds me of a human face, and to this one with its face turned toward me, I felt like apologizing for disturbing it.

On my walk back to the house I passed many varieties, and marked the spot of those I wished to secure, and promised each an early visit.

The sun had set long before I reached the ridge, and near the top I found my friend anxiously waiting my return.

"You have remained out too late," she said. "The Arroyo is a dangerous place after the sun has disappeared from it."

“Tramps!" I asked in alarm.

"Oh! no, no tramps, but those that tramp in it are in danger from the damp chilly air that takes the place of the sunshine. But come, a good hot cup of tea will make you all right."

Every moment spent in and near this beautiful place was a delight to me. The days were too short, was the only regret I had while here, but every hour from the moment the sun made its appearance until it disappeared, found me, like the lovely flowers, enjoying its rays, and like them I thrived on it. 




$$
\text { 䉥 }
$$





\section{CHINESE CIGARETTE BLOSSOM.}

While I was visiting Pasadina, my friend took me to drive, and we paid a visit to that most interesting of all missions, "San Gabriel."

The Spanish woman in charge was found. She came with the huge key in her hand. She looked at us for a moment, then opened the great door with her great key and walked in ; we followed. As we stepped upon the stone floor, worn smooth with the thousands of feet belonging to the thousands of souls now in eternity, a feeling of awe came over me. The Spanish guide motioned us to go up to the chancel. I would have obeyed her had she commanded me to kneel, or take any other position, so helpless and insignificant did I feel. We went up to the chancel and the guide pointed to the altar; not a word did she speak. I wished she would, but I had not the courage to address her in this sacred ancient place. The carvings and brasses about the altar were quaint and very old. My friend, who was a good Christian woman, whispered, "Do you believe these carvings represent the Apostles?" I could not answer her, neither could I prevent a smile. Oh! fatal smile; the guide saw it, and with her finger motioned us toward the door. We walked out like two culprits, and if the little windows had not been up very near the roof, I am sure I should have tried to escape through one.

At the door we met a party coming in. Their guide was a Spaniard and spoke English. He handed his party over to the 
silent Spanish woman, and asked most politely "if he could be of any service to us." I told him of my errand and desire to secure something from this interesting place. He "would be most happy, senora," and leading us through the old house of the priests into the grounds of the mission, we found ourselves among the tombs of the monks, one of which attracted my attention. It seemed the oldest. The inscription was entirely gone, and across the top the bees were going in and out through a large crack. It made me think of the court riddle so familiar to all, "As they went out and in again, from the dead the living came," etc.

Growing near, with its branches shading the tomb, was a Chinese cigarette bush. I selected this bunch of blossoms in my sketch because it was the nearest to the tomb and the wind swayed it back and forth over the ashes of the monk who had rested there more than a hundred years.

The missions of California are very old and interesting. Lower California was entered by the Jesuit missionaries in 1697. The first mission founded was in 1769 . They built in all twenty-one mission establishments. The last built was in 1820 .

They selected for their sites the garlen spots of the peninsula, and throve remarkably until i 822 , when Mexico became independent of Spain. This event was a death-blow to the Franciscans' establishments, and from that time forward they lost ground, and in 840 were broken up altogether. 




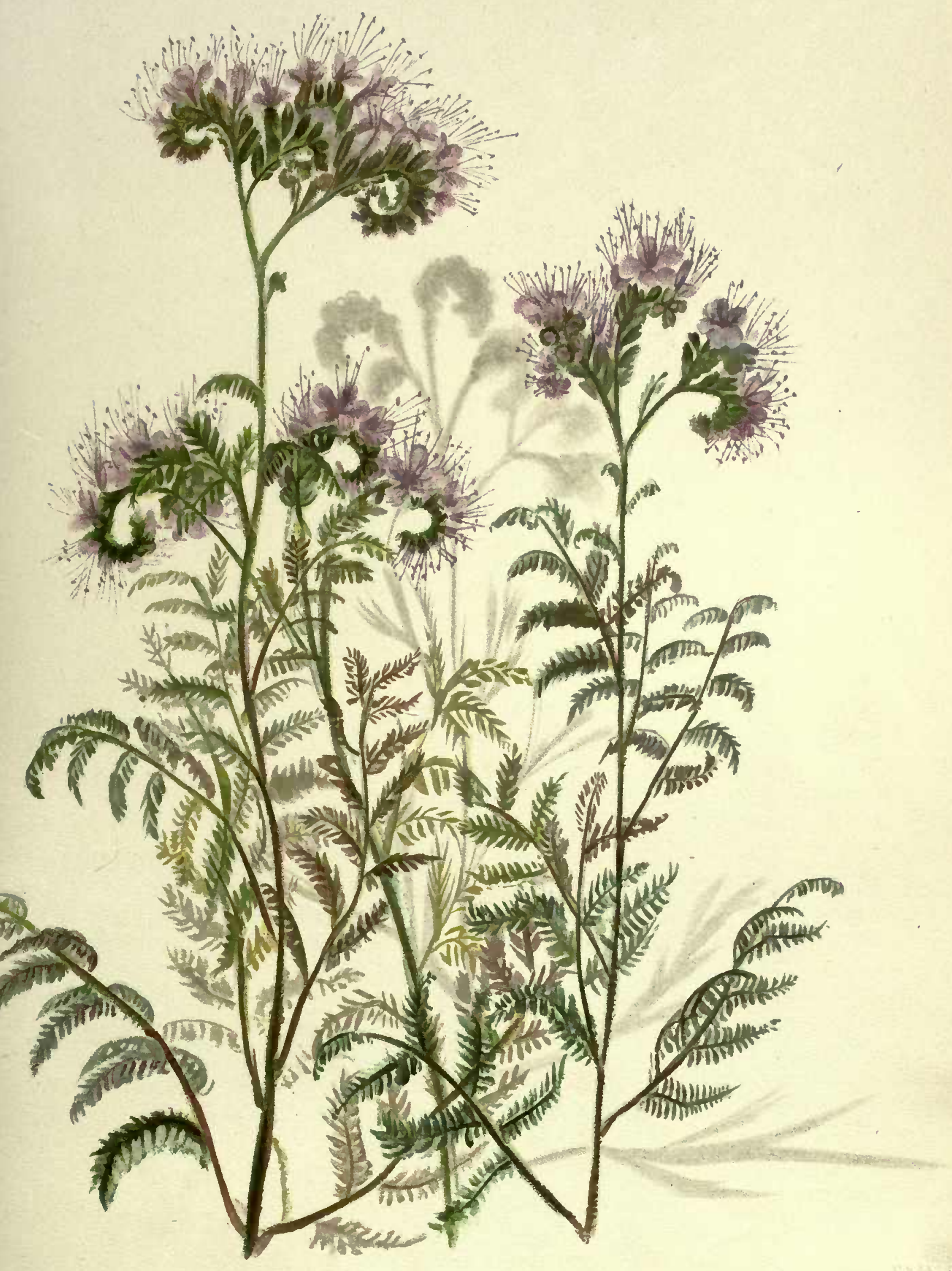





\section{WILD HELIOTROPE.}

It was my second day at Los Angeles when some friends calling, said, "We are going in the country for the day, will you come with us?"

"Yes, I would be so glad to go." We drove toward Pasadina, and when a few miles out we chose a pretty spot, cool and shady, and prepared to remain the day.

The country between Pasadina and Los Angeles is very beautiful, and the place chosen for our picnic commanded a view of the country for miles around. In the distance we could see the handsome hotel called "The Raymond," a portion of Pasadina and the City of Los Angeles.

A new town was being laid out near, and the hundreds of men in their red flannel shirts, with shovel and spade glistening in the sunshine as they flew in and out the ground, made a pretty picture.

I found many varieties of wild flowers here : the Mariposa lily in great abundance, and was about to choose it for my study, when a little girl in our party came running to me.

"Oh! come and see what a beautiful flower I have found. I did not pick it, for there were no others like it. Do come."

I went with the child down in a ravine, and there found growing on a little mound this lovely heliotrope. It stood alone with the lavender blossoms on the very top, spread out like little plumes. I thought it so beautiful and wonderful. It was 
the first wild heliotrope I had ever seen. Since then I have seen acres of them in full bloom, but they have not lost their beauty, and will always remain my favorite flower.

I gave this sketch more time than any other in my collection, the flower is so finely marked and delicate in its growth.

A stranger entering Los Angeles finds it difficult to understand what nationality claims the city. We see the little adobe houses of the Mexicans, the most of them with no windows, the door letting in the only light. Now and then a Mexican family can be seen sitting on the steps and in the doorway chatting and laughing and seemingly very happy.

A little further on the Chinaman places his name above the door, and one is told in very bad English that Wang Lee and Wong Tong and many other Wangs and Tongs will do your washing cheap.

We turn the corner of the street and meet the Spanish woman with her headdress of Spanish lace, and her coal-black eyes that are ready to snap if you do not give her more than half the sidewalk. And, anxious to give her all, we run against an Italian, whose tall, slender figure looks taller as we make our apologies and he bows in turn his acknowledgment.

A Frenchman waits upon us at table and a German servant will tell you the city was settled by her country people.

Americans you find here, some for their health, others for the lovely climate, choosing it for their winter home.

Flowers blossom all winter long in the gardens, like a perpetual spring. 




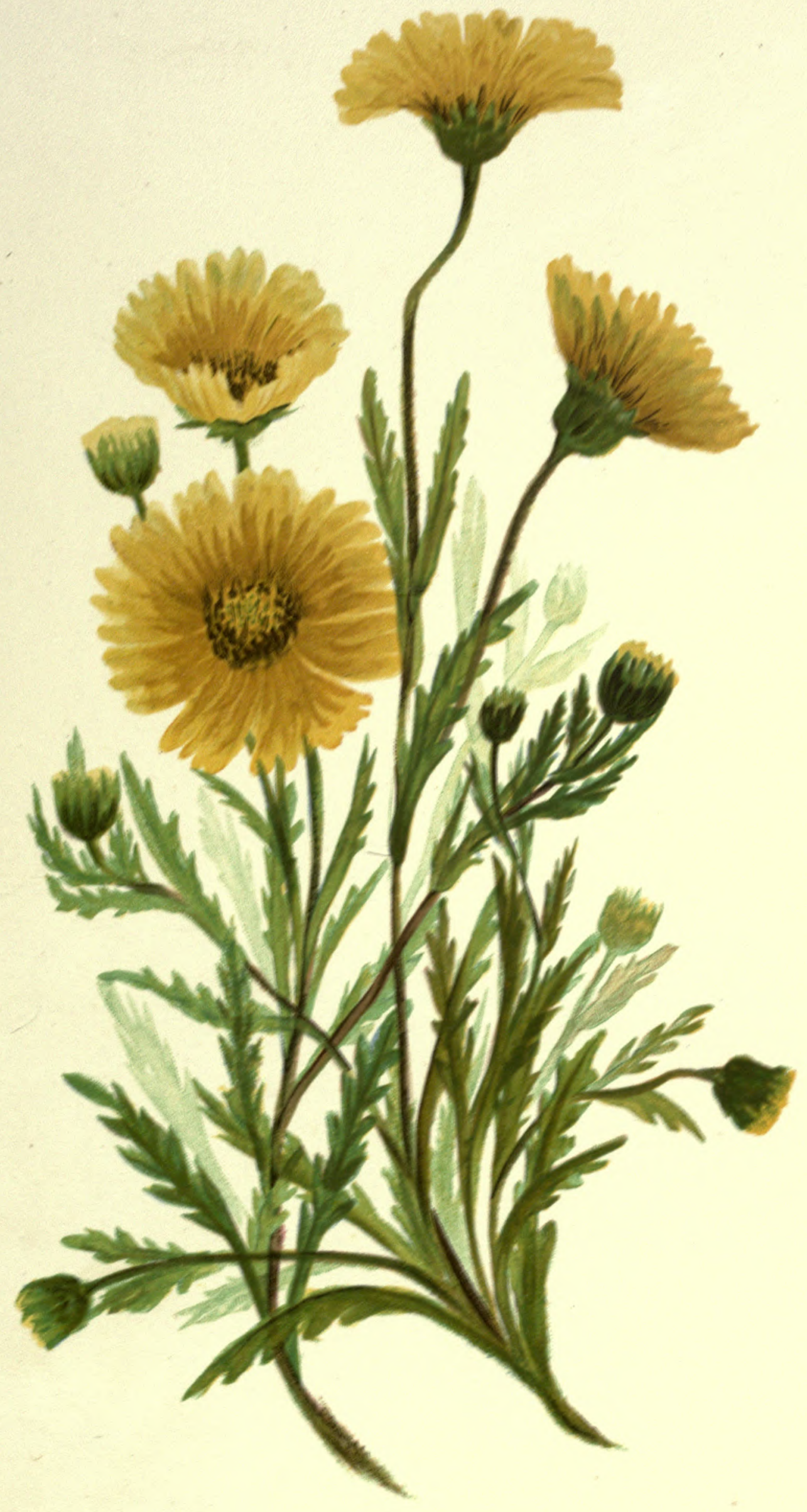





\section{“TIDY-TIPS."}

Does this bright stylish blossom look as if it could in any way be connected with a Chinaman? Well, it is, for to one I am indebted for it.

It was while I was at Santa Barbara a young Chinaman was the chambermaid of the house in which I was stopping. He did up my room promptly and neatly; he always wore white and it was white, not a spot or wrinklc in his suit.

While at Santa Barbara I made many sketches, finding the flowers at this place very fine.

I noticed that John made numerous trips near my table while tidying up my room, and I know he was watching my brush as it washed in the colors.

Spending a morning out in search of something new, and not finding it, I came home tired, and I fear a little cross. I met John near the door, but did not notice him, and went directly into my room. There I found in a glass of water on my table these handsome tidy-tips.

"Oh," I exclaimed, " they are just what I have been looking for! Where did they come from?" They were prettily arranged and looked fresh, as if just picked. There was no card. I would go to the office and inquire.

As I went out into the hall, there stood John, and smilingly asked :

"You likee?" 
"Oh, yes; very much. Where did you get them?"

"Woods, pickey," and he was gone

When my sketch was finished, I asked him how he liked them.

He danced about, first on one foot and then on the other, and grinned.

"Me likee much; me likee big!"

We hear much about the Chinamen, and little in their favor, but during my stay on the coast, I found them excellent servants.

While in San Francisco I went with a large party of friends, protected by a detective, to the Chinese quarters. I went into the cellars, and saw the old blind woman and her cats, "the joss house" and the opium dens, and saw the inhabitants stowed away like so many sardines. But I must not surround my pretty tidy-tips with this dense atmosphere. They came from the lovely woods where the air is pure, and the sunshine beautifies every thing it shines upon. There is no place it shines more beautifully than at Santa Barbara. My visit there was after the rainy season, and every thing in Nature was fresh and lovely. The clouds had disappeared, the small white watering-pots of heaven, each one trying to outdo the other in their sprinkle, had exhausted themselves and floated away to rest, leaving the sky clear and blue for the rest of the year. 
. 



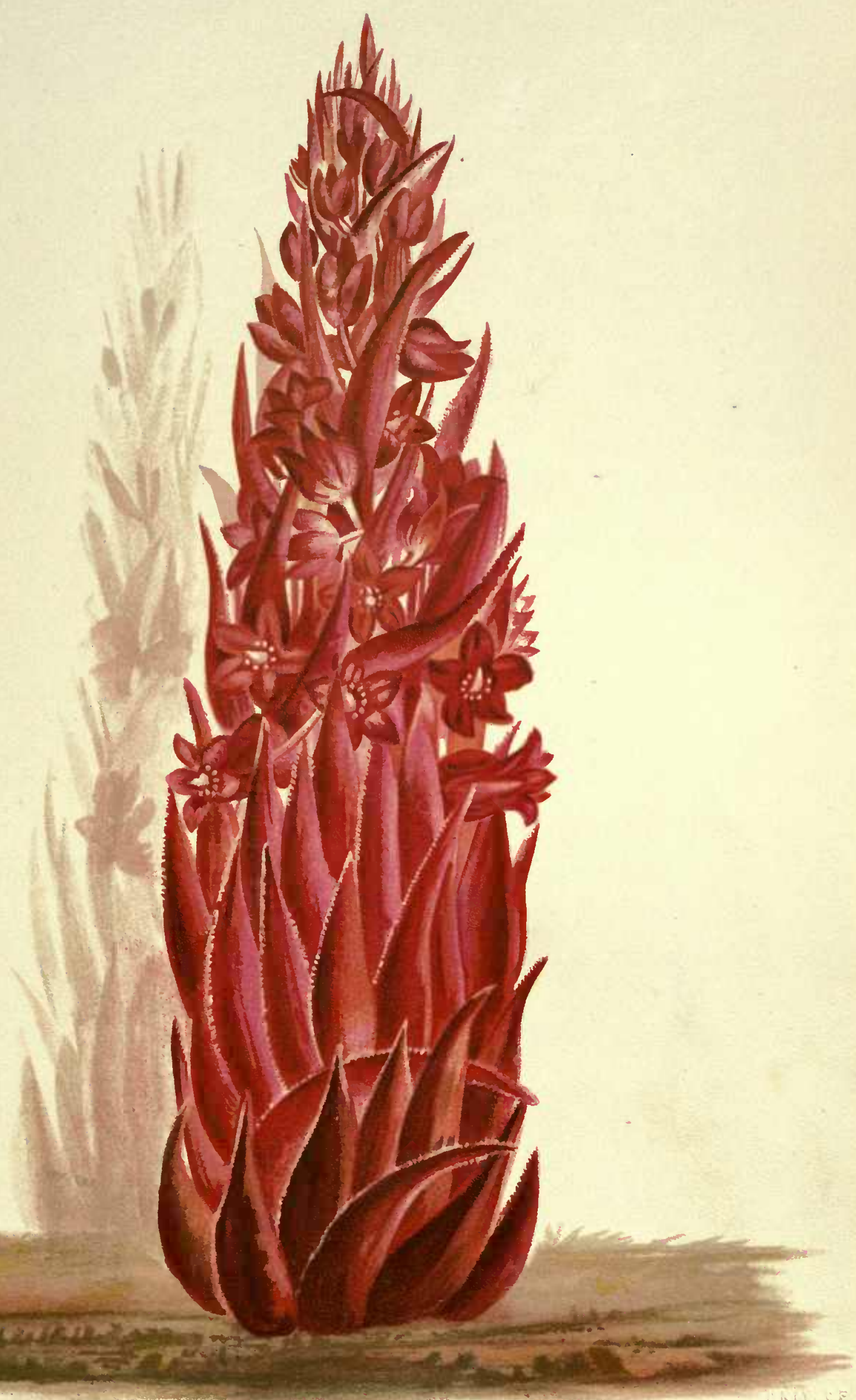





\section{SNOW PLANT.}

After our arrival in the Yosemite Valley my first inquiry was:

"Where shall I be likely to find the snow plant?"

"On Glacier Point," answered the polite attendant.

"I will go there; how soon can I leave?" He looked at me a moment before answering: "You are obliged to start in the morning. It is a day's trip, and you need three very important things: A steady head, a good horse, and an experienced guide."

"I have the head, and if you will engage for me the horse and guide, I will be ready to start in the morning." An English friend and his wife joined $m e$, and we left the next morning at seven o'clock. Our guide was one of the best in the valley, an Indian by birth.

Our horses were regular trail horses, and were not to be guided, so we gave them the rein but kept a firm hold for fear of their stumbling.

About half way up, and as we came to a wider trail, called the " meeting place," I ventured to look down. Never shall I forget the sight. It happened to be directly opposite the Yosemite Falls. The day before I had looked at them from the porch of my hotel, and thought them thousands of feet high; now I looked down upon them, and could see the river on the mountain which gave them their supply. They were grand 
beyond description. On comes the river until it reaches the edge of the precipice, then it becomes a raging, roaring mass, sending thousands of glistening diamonds into the beautiful veil of soft mist below.

Our guide reminds us it is time to start; we mount our horses and turn with regret from the beautiful sight. The path now becomes more narrow, the turns sharper and more difficult. On one side the mountain, on the other, and within a few inches, a chasm over two thousand feet deep. We are silent, not a word is spoken until the English lady exclaims to her husband, who is just behind her, "Oh, John! take me off or I shall drop my head."

"Keep your seat, madam," shouts the guide- " in a moment we shall be on Glacier Point;" and so we were. Suddenly the path widens, and we find ourselves on a beautiful plateau, with a forest of trees in front of us, at the edge of which stands a pretty little hotel.

After a good luncheon, I start out with the guide to find the much-coveted snow plant. After riding through the wood for a mile or so, we find three fine specimens. The snow was just disappearing from the ground around them, and they looked like little monuments of red ice glistening in the sunshine. It is their own natural glisten that makes them so wondrously beautiful. The color and drawing of my sketch is correctly given; but for the "glisten," think of it as a mold of red ice, this shape and color, with the bright sunshine upon it, and you have some idea of the wonderful flower. 


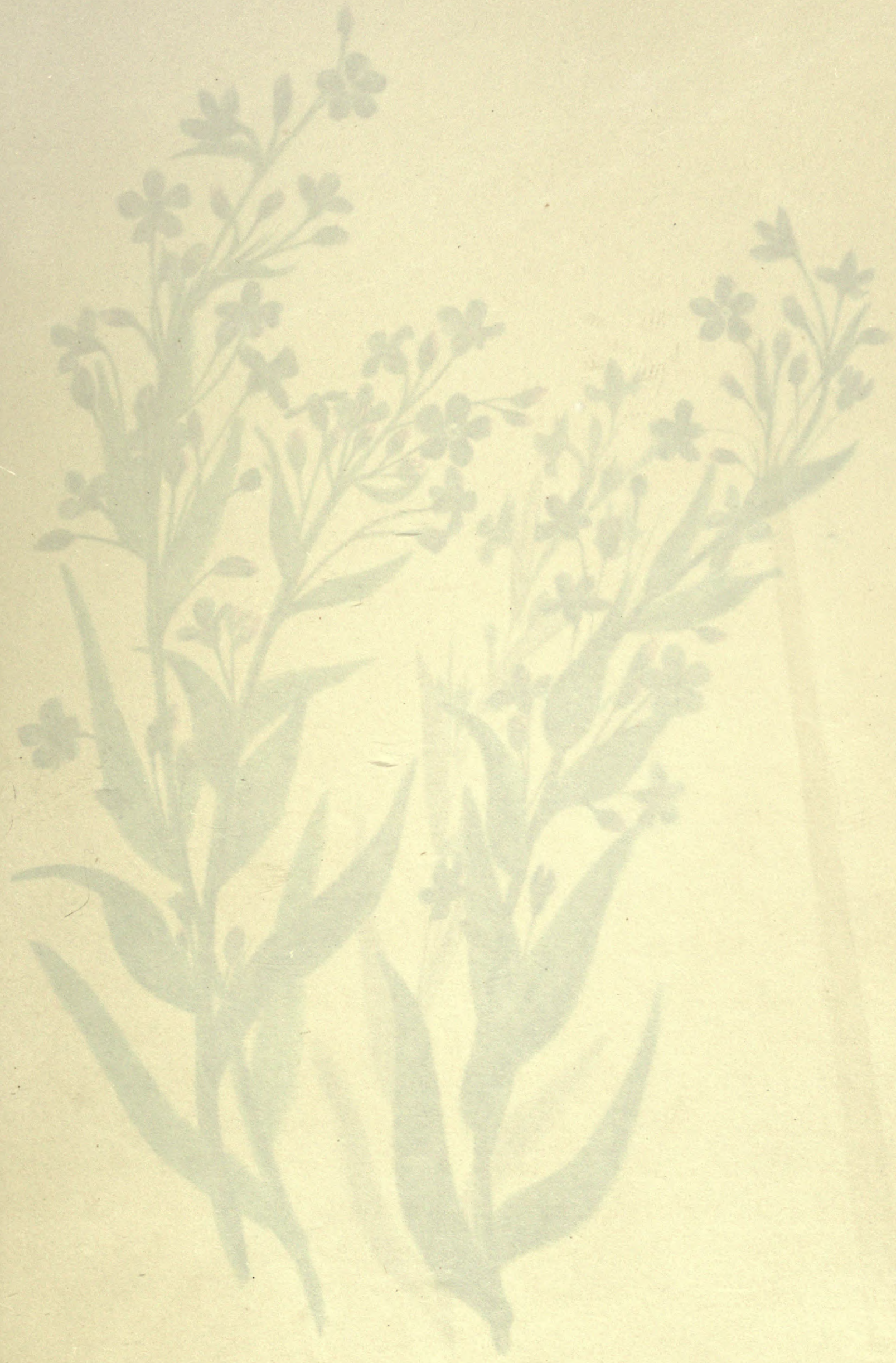





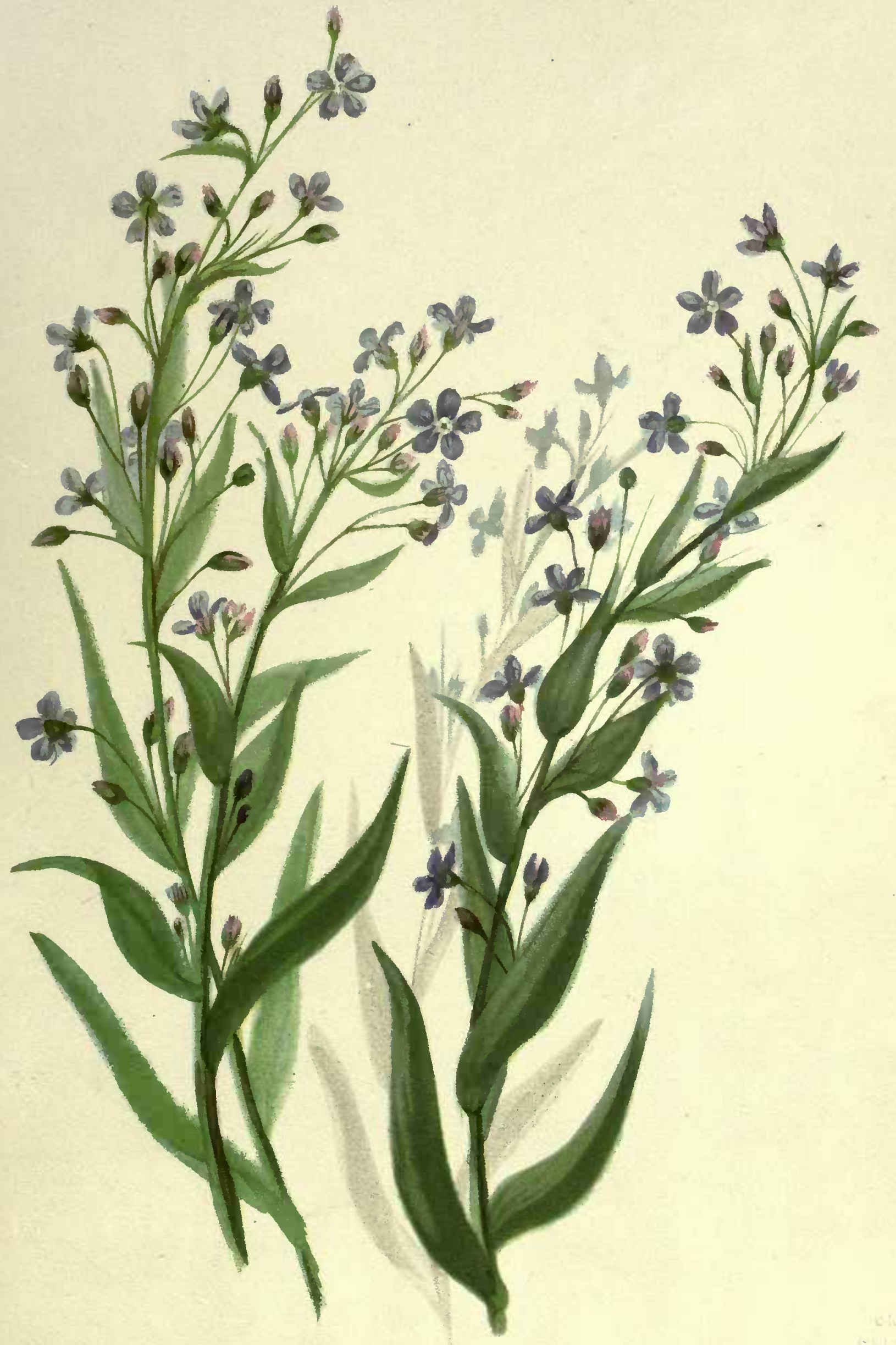





\section{FORGET-ME-NOT.}

It was while we were on Glacier Point, and after a good night's rest, that we paid a visit to the Dome, a point in the mountain the highest I ever wish to visit.

While our guide led the way through a forest of beautiful trees, it was difficult to imagine ourselves on the top of a mountain thousands of feet above the Yosemite Valley.

We follow on a well-beaten path, and as we ride along see many varieties of wild flowers; here and there the snow plant stands, dignified and alone, like a little red sentinel keeping watch over the aerial domain.

With every step we are going higher and higher, but so gradually we do not notice it. Then the ride is so cool and pleasant, we are thoroughly enjoying every moment. Here and there we see lying on the ground the trunk of an immense tree that is fast going to decay, and we know from the living trees and their reputation for hard and lasting wood, that these monsters must have lain there for scores of years; and while every thing is so new and wonderful to us, it is not easy to imagine it has been just the same, with the same trees and rocks, for thousands and thousands of years.

The absence of birds was noticeable. Not a note did I hear while making this trip to the Dome, and yet the place was most inviting for them. They may be there at different seasons of the year, and it may be some important meeting called them 


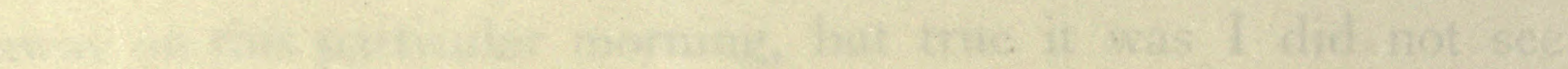

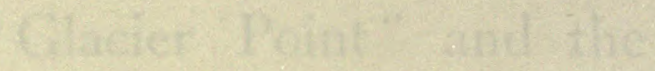
$x^{2}-x^{2}$

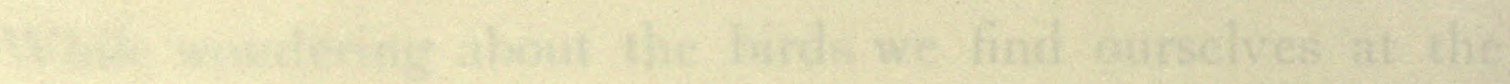

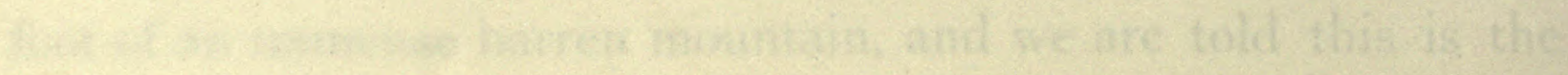

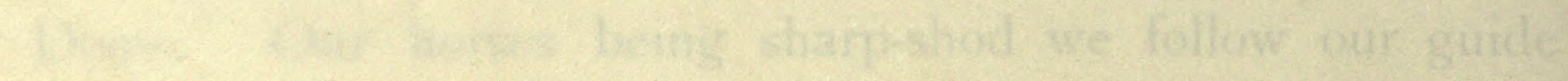

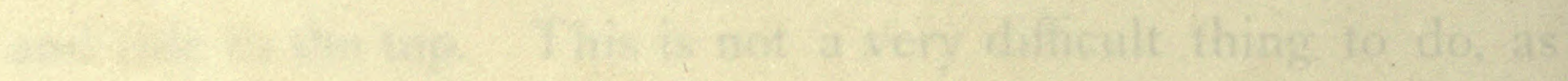

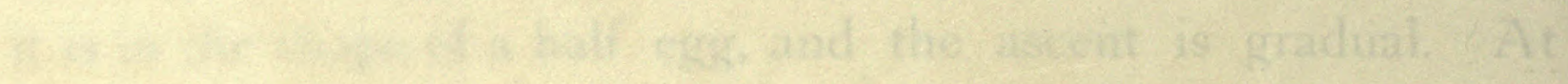

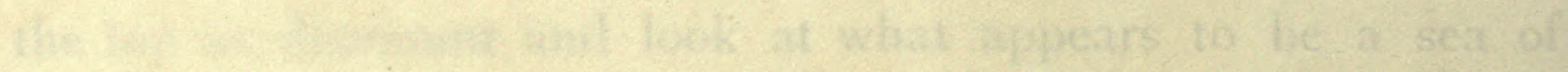

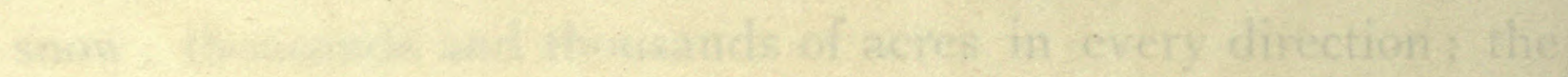

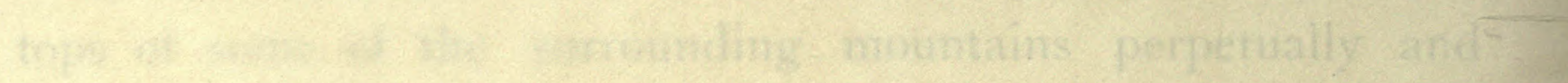

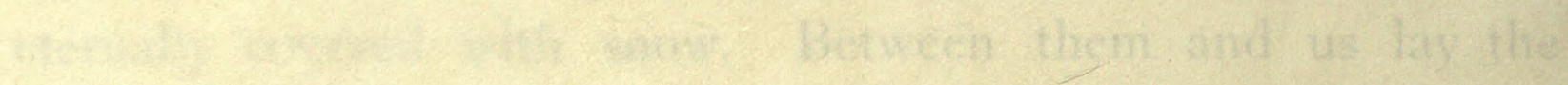

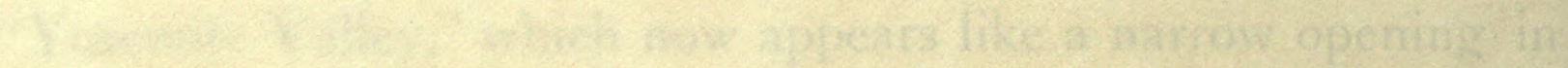

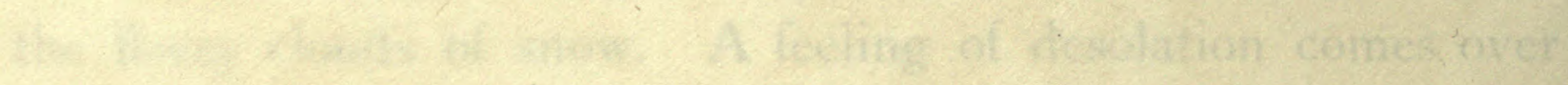

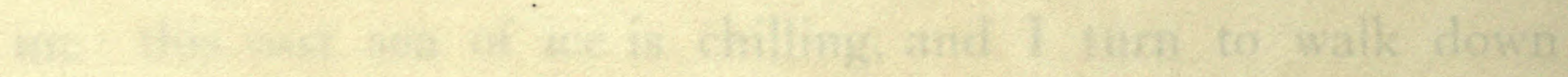

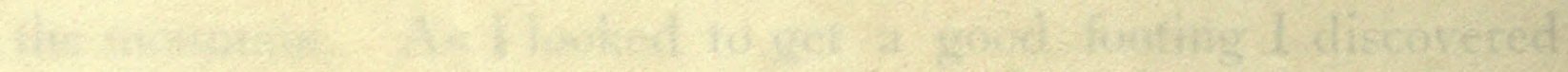

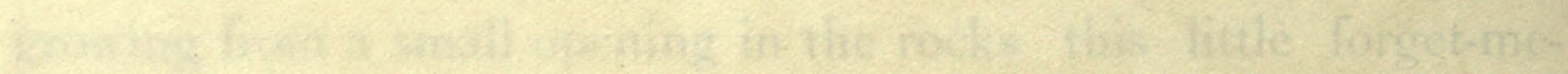

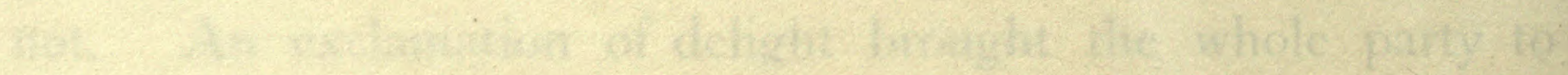

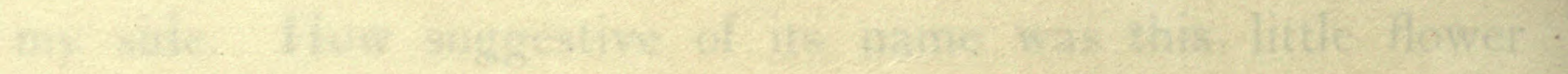

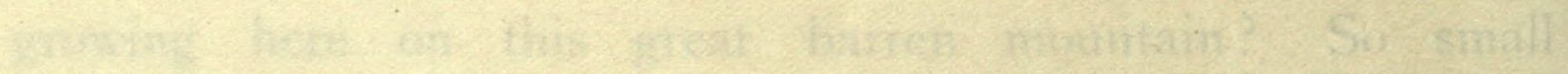

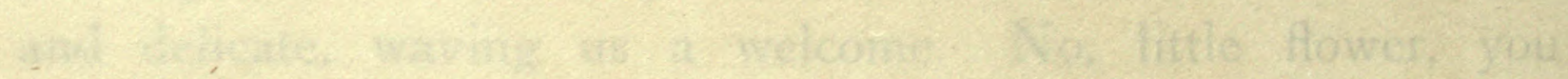
.

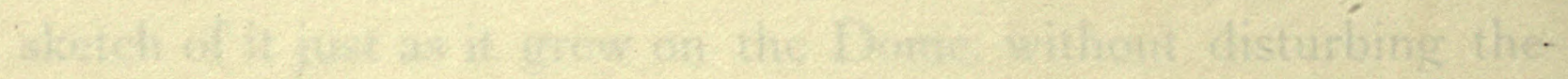

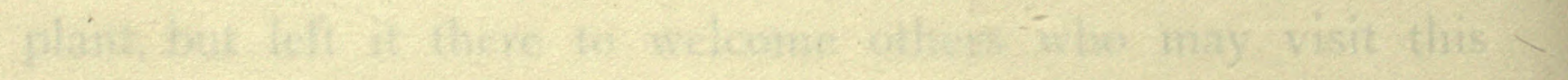

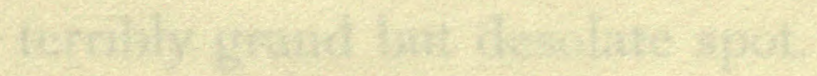




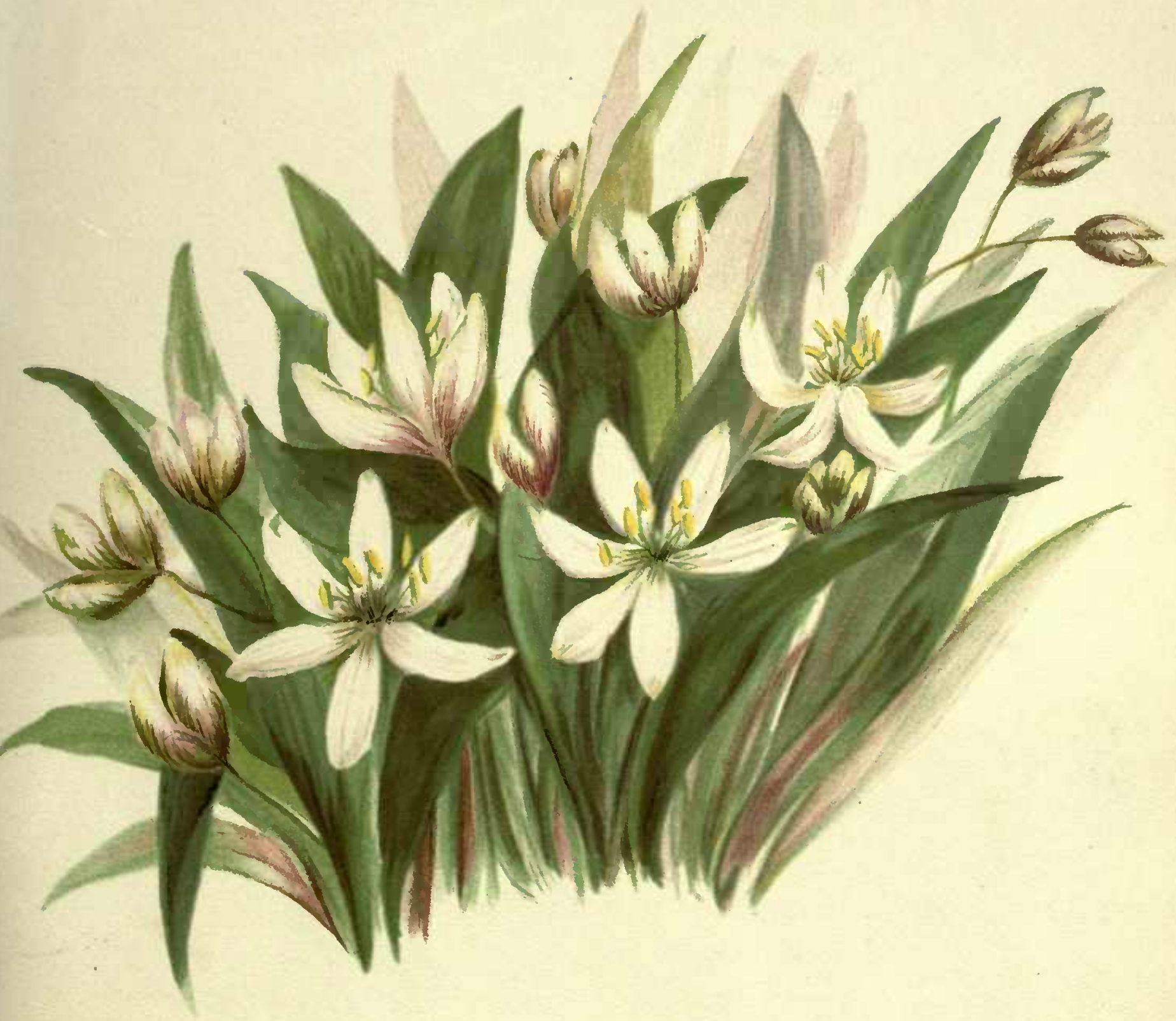





\section{WOOD LILY.}

This pretty cluster of lilies I found in the woods in the northern part of Oregon, through which runs the Oregon Short Line Railroad.

Long before the train stopped for dinner, I had noticed little white flowers along the road-side, but so swiftly did we go I could not tell even the shape of the blossoms. When the dinner station was reached, I had a promise from the conductor that he would not leave me; so, while the others were taking their dinner, I went into the woods and found this pretty cluster of white lilies. They grow in little clumps, just as I have given them to you. I carefully dug up this bunch, and arrived at the car just as the passengers were ready to enter it.

Making inquiries, I found I could spend the night and day at the little house used for an eating station, and I decided to remain over until the next train.

I spent the afternoon in making my sketch. Having given up my dinner, I relished an early tea. Then came the twilight, - a scene I shall ever remember. The sky became a delicate pink, then gold, as the setting sun disappeared behind the forest. The voice of the birds was hushed.

The little house which was to shelter me for the night was the only one for miles around, and was situated in the heart of the great woods. It was so quiet and peaceful, a rest I had not known for weeks came to me. The people who kept the place seemed 
to feel the same quiet, and did not, as was often my experience, ask questions. The longest remark put to me during that beautiful twilight was:

"If you think this is fine, get up at five o'clock to-morrow morning. It'll pay you. The birds will keep you company - plenty of music then."

I took the advice, and, as has been said, "it paid me." As the sun cast its glorious rays above the tree-tops, it seemed as if thousands of birds sang to it their welcoming song. The fresh morning air, laden with the perfume of the woods, with its countless varieties of wild flowers, was so sweet and refreshing I wished the whole world, or the people in it, could enjoy it.

From this little station to Portland was just a day's ride. The following morning found us gliding along by the side of the Columbia River, whose scenery I consider far more grand and beautiful than the scenery along the Hudson River. The banks of the Columbia are covered with beautiful trees and flowering shrubs. Waterfalls that resemble the falls in the Yosemite meet the eye as we pass along. The river is as clear as crystal, and the reflections of the mountains are so perfect one can scarcely tell which are the real.

Beautiful ferns and flowers are everywhere. Just before reaching Portland and at the foot of the "Bridal Veil Falls," I saw some ferns that surpassed in beauty any I had ever seen under careful cultivation. Holding their stems up straight, they came far above my head, and were as fine and delicate as the "maiden's hair" fern. 




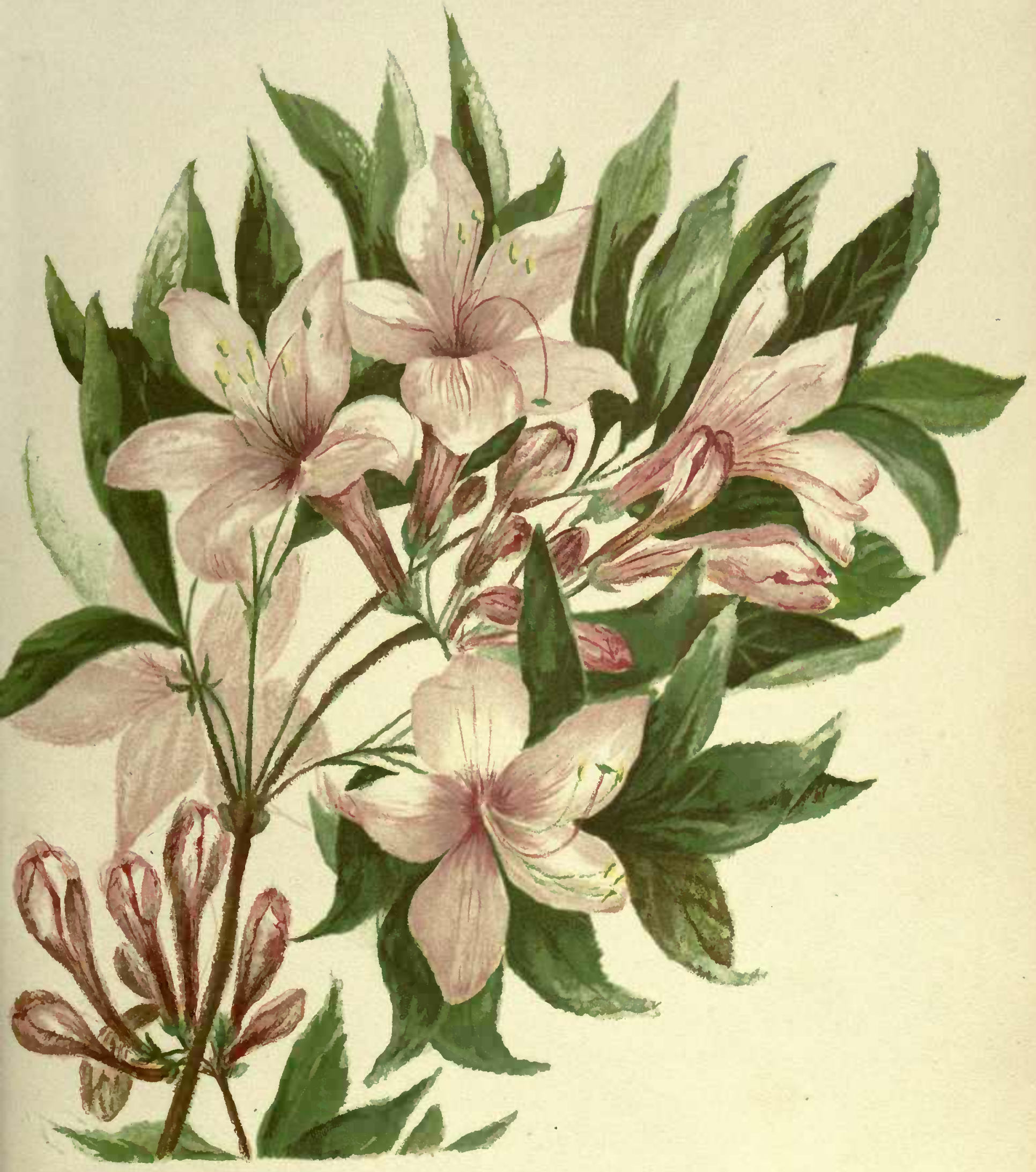





\section{AZALEA.}

It was while visiting the Mariposa grove of big trees I found the azalea: a fine shrub growing from four to six feet high, and bearing a blossom large, and rich in color, from pure white to a deep pink; I am told the red and crimson are found, but I did not see them.

This little bunch I have given you in my sketch I prized above all others I saw while in the valley.

We were on our way to the grove. The horses were walking, and we were admiring the beautiful scenery, when suddenly we heard a "Hello!" and the echo answered "Hello!!" The driver stopped his horses and looked back. "Oh, it's old Rippen," and he called, "Come on, I'll wait for you."

An old man came panting up the hill.

"I knew you would, Jim. I thought this was your day. Load light or heavy?"

"Neither; but room enough for you. Take the back seat."

As he climbed in I saw in his hand a bunch of azaleas, the most beautiful blossoms I had ever seen. He saw me looking at them, and said, "Fine, ain't they? You'd see nothing like them in the valley. I went out of my way purpose for them. I press flowers, madam, and there ain't much in the valley but what I have in my collection. Have you noticed the trees?"

"Yes, I have, and greatly admired them." And I soon discovered that this old man possessed a knowledge of the trees 
to be envied. He knew the name of every tree from the largest to the smallest shrub.

The trees of California, especially in the Yosemite, have a grandeur of character hardly surpassed in any part of the world. Of the pines, the sugar pine (Pinus Lambertiana) I think the finest, often reaching three hundred feet in height, straight and dignified in its bearing, with the trunk clear of limbs for twenty and often thirty feet from the base. To stand on the ground and look up at its top branches is like looking miles high, and one can imagine the sun shining on its highest leaves, while night has nearly overtaken the enormous roots that are in places from one to three feet above the ground-come out, as it were, to look after its young branches that every year are growing further and further away from their parental care.

Of the other trees seen on our trip, one I remember with special interest is the red wood (S. sempervirens). Magnificent forests of the red wood are found in the counties north of San Francisco Bay, and are limited exclusively to this one species. Another beautiful tree is the laurel (Tetranthera Californica).

The well-known ornamental tree, the Pinus Insignis, found near Monterey, and the cypress (Cupressus macrocarpa), of which there is a magnificent grove at Cypress Point, are valuable to the State. These are but a few of the names of her grand collection, and California has cause to feel proud of the finest collection of woods in the world. 




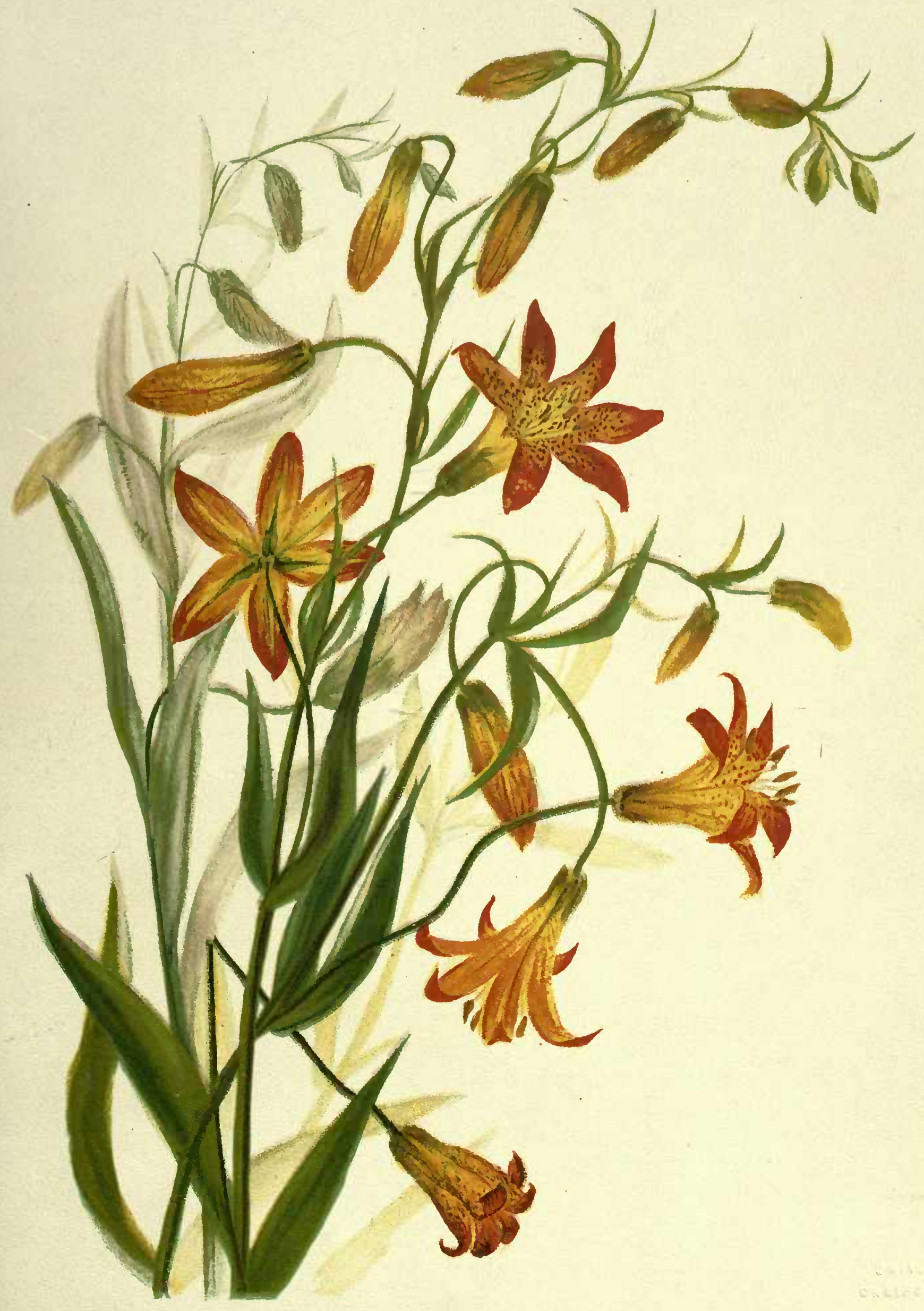





\section{SPOTTED LILY.}

Every tourist who goes into the Yosemite Valley is visited soon after his arrival by a young man, who informs him of the many places of interest, how to get to them, what hour to start, and all information that it is possible to give concerning them.

You can visit all, or if you are proof against persuasion, you can make your choice. I would advise you to make as first choice after the long stage ride, a visit to "Mirror Lake" and through the valley. It is casy, restful and grand.

To see the perfect reflection you must be at the lake just as the sun is rising. The morning I went we arrived there, our guide said, at precisely the right moment. The lake was waveless as a silver floor, the reflection perfect. As we look we see Cloud's Rest, and the little flag is waving. Oh! and there is "Mount Watkins," and yonder "South Dome." The sun is shining on the cathedral spires and reflected on "El Capitan." As we gaze down into the lake we wonder which is the real, and wondering we become infatuated with the scene, and gaze until the guide reminds us the time is up. As I turned from the lake I changed my position and gave another look, and saw in the water these pretty spotted lilies I have given you. The colors were as bright in the shadow as those in the sketch. they were the only lilies growing near the lake, and I thought 
them worthy of being reflected on paper, and a pretty souvenir of one of the most beautiful lakes in the world.

We continued our drive through the valley, and our guide took us as far as "Inspiration Point." Words are too tame and insignificant to describe the view from this point. In front "El Capitan" stands in one magnificent perpendicular line from base to summit, three thousand feet high, standing guard over the valley broad. Opposite this mighty monster, and falling at its very feet, as if doing homage to its greatness, is the "Bridal Veil Falls." Beautiful, fleecy, swaying foam, bounding through the air nearly a thousand feet, and casting its spray like a blessing on all who pass it.

Next is seen the Three Graces, with the soft purple shadows thrown like garments about them, and then the "South Dome," and further on the summit of "Cloud's Rest;" and now we are in the valley, and driving quietly by the side of the lovely Mercede River we pass the wigwams of some of the native Indians who act as guides and fishermen in the valley. They will catch the speckled trout when other fishermen, with their fine fishing-tackle, leave discouraged. The women pick berries and sell them at the hotels, and their bright and artistic dress adds much to the beauty of the surroundings.

Our guide takes us to see the site selected for the grand hotel which is to be built; then to our hotel where breakfast awaits us: the spray of the Yosemite Falls cooling the air, while we eat the trout caught by our guide in the early morning before our start. 




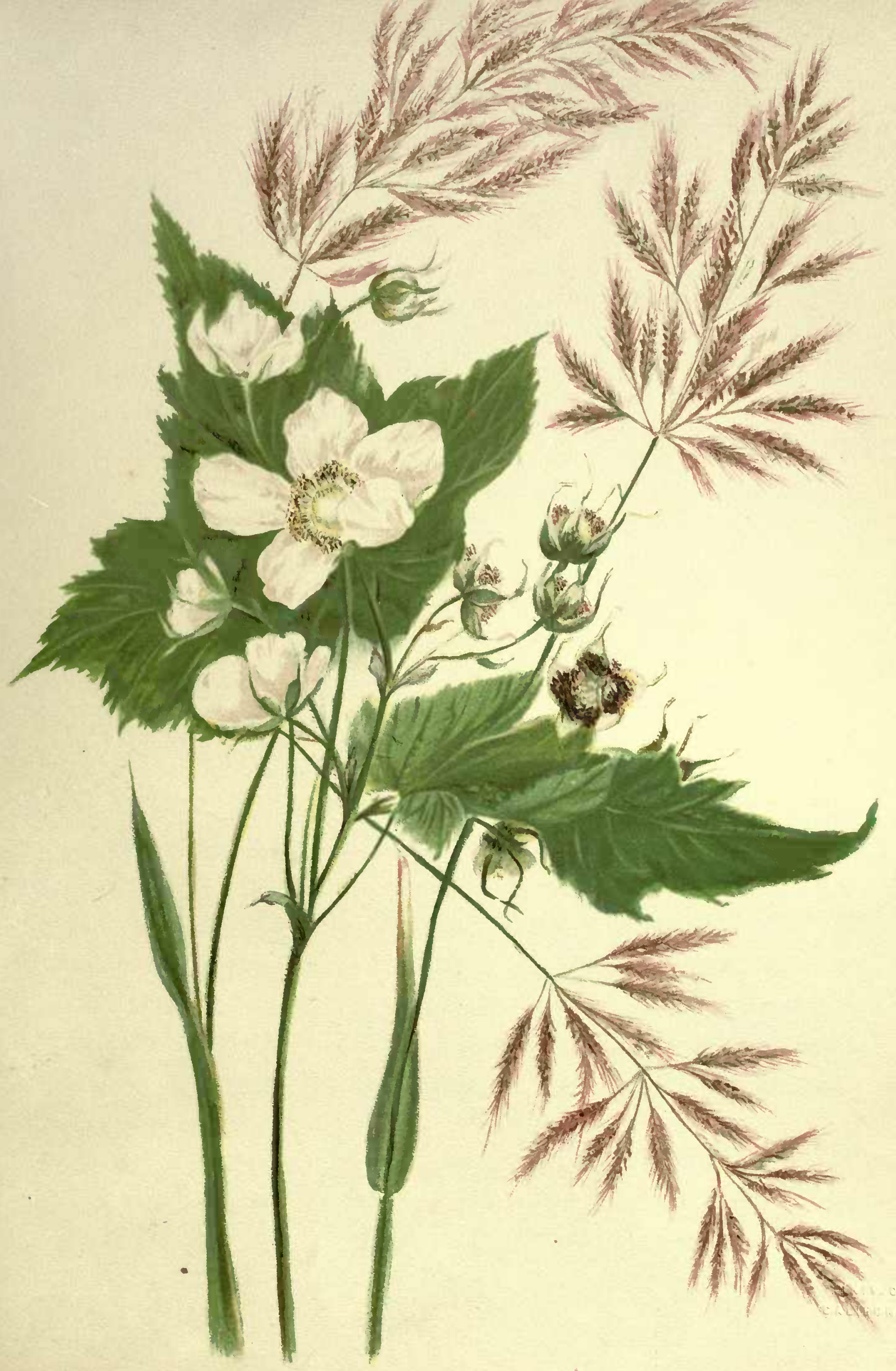





\section{SALMON BLOSSOMS AND PINK GRASS.}

The advertised time for the steamers to leave Portland for San Francisco is midnight. Long before that hour the passengers had taken possession of their state-rooms. At ten o'clock the main saloon presented a gay scene. We had three bridal parties on the boat. Each bride had her many friends, and each friend brought flowers. The odor of the flowers, the merry voices of the bright young people, and the many colored lights from the handsome chandelier thrown upon them, made a bright and pretty picture.

By eleven o'clock the saloon was quiet, all had retired, and when the huge wheels turned quickly in their start, sleep had taken possession of the passengers.

The early morning found us on the Columbia River. The sight that greeted us as we came out on the guards was grand and impressive. Hundreds of small salmon fishing smacks could be seen in every direction as we neared Astoria. The fishermen had stretched enormous nets across the river, and on two occasions our steamer cut through them, much to the consternation of their owners, who, seeing the danger, vigorously attempted to draw them in, but were obliged to abandon them as the great steamer cut its way, regardless of the damage it was doing to the valuable property of the fishermen.

Salmon fishing is the principal occupation of the male population of Astoria. A man owning his little sailboat and fishing nets is considered to have a good start in life. Immense 
canning factories are situated here, and the finest canned salmon used in this country comes from Astoria.

The captain informed us our stop at Astoria would last for several hours, as the freight from this point was very heavy. The little town is built on the side of a hill, and commands a fine view of the river and surrounding country.

We walked to the top of the principal street to see what once bore the dignified name of "fort," and was told that "Right here on this spot John Jacob Astor built his fort and made his first trade for furs with the Indians." On the very top of the mound grew this fine salmon blossom, and a few feet away a bed of tall pink grass, the finest I had ever seen. It waved and nodded in the warm breeze, as if inviting me to select its finest bunch to keep company with the pretty white blossoms that had been its neighbors, and from whom it was loth to part company.

Our stay at Astoria was quite long enough to give me time for making my sketch, and by the time the "All aboard" was called we were ready for the good dinner that was waiting for us. How handsome the cabin looked with its two long tables, every seat filled, and all seemingly bright and happy. The brides had been ashore and gathered wild flowers, which were artistically arranged in their belts. It was a pretty sight, and to be witnessed but once on that trip. At three o'clock we crossed the bar, and I, like the majority of the passengers, took my berth, not to leave it again until the Golden Gate was reached, and San Francisco was in sight. 




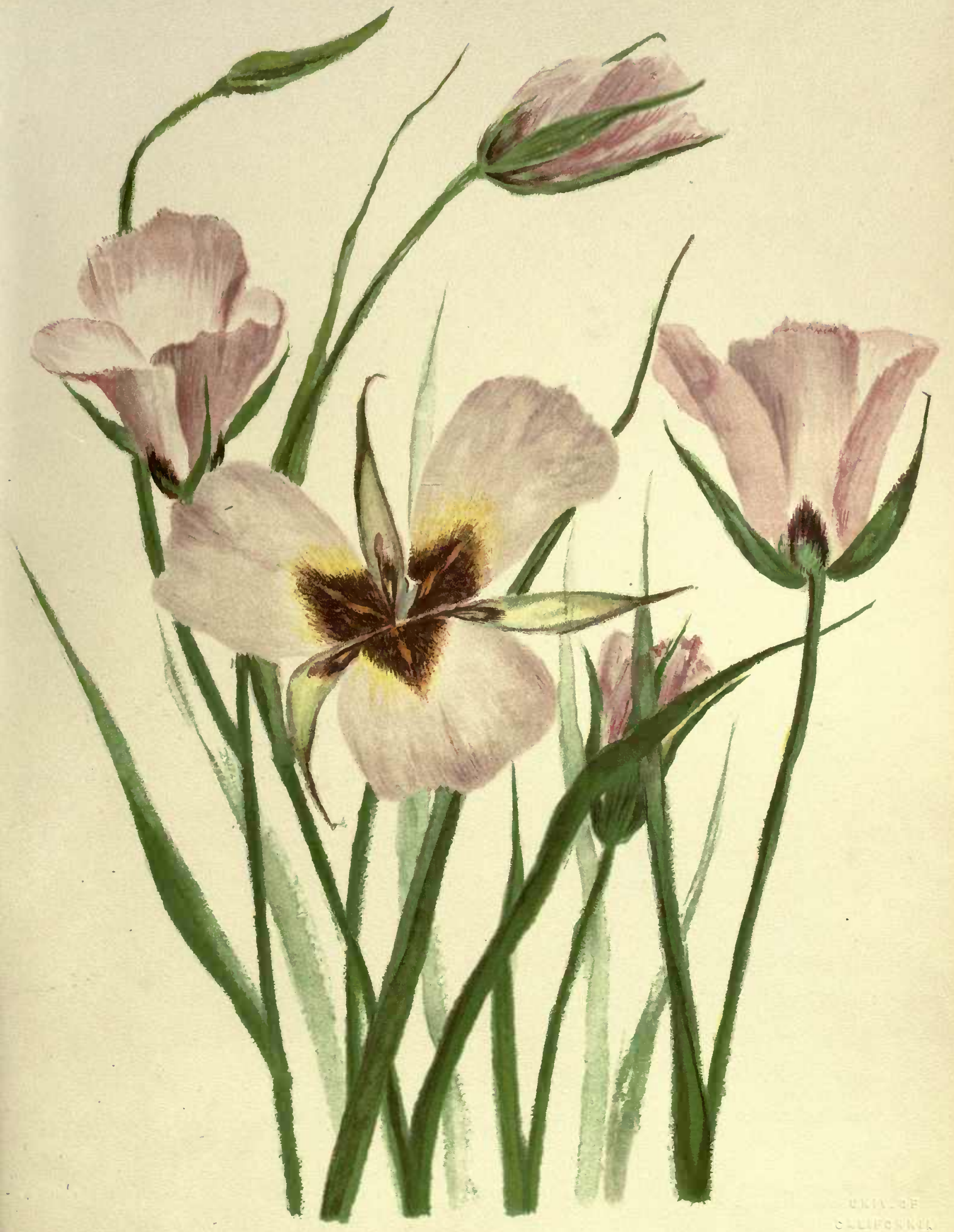





\section{MARIPOSA' LILY.}

It was on our way out from the grove of big trees that I found this lovely lily, - a bed of them, in which I counted fourteen distinct markings. Every passenger in the coach got out to look at the bed. It was not large, being about four or five yards in circumference, and looked as if planted and protected by some careful hand. The flowers looked like so many butterflies, with wings outspread ready for flight, their rich colors glistening in the sun.

Mariposa county is named for this flower, as also the grove of trees we had just left.

A feeling of awe comes over me when I think of those giants of the forest, standing here and there as guardians of that mighty family.

With the exception of "The Brothers" they do not grow close together, and if they continue to grow as much in the next thousand years as they have in the past thousand, they have made a wise choice in securing ground room for growth.

Much has been written of the "Wawona," and it is a duty, as well as pleasure, for each visitor to drive through it. Our coach, drawn by six horses, took us through the opening, and plenty of room to spare. All of the large trees show signs of fire being made on the side of them, and it is supposed the Indians had their fire-worship here. I could well understand their love and worship for these living gods. As Nature is 
their worship, what could be more grand in nature than these?"

The tallest big tree yet discovered measures three hundred and fifty-two feet in height. The circumference of the largest, near the ground, sometimes reaches nearly one hundred feet; many are over fifty feet in circumference at six feet above the ground.

The cones of the big trees are small, some of them only one or two inches in length, but very regular and handsome. We spent the first night out at Washburn's. 'The start in the morning was at four o'clock. As we reached the top of the first hill the sun was just coming up, and a more glorious sight I never expect to witness. The grand forest on one side, with its branches garlanded with golden moss, glistening with the first rays of the rising sun. On the other side the valley below us, with the sun shining through the rising mist. The spirited horses seemed to feel the inspiration; the leaders turned the sharp angles in the most graceful manner. There were but two passengers this morning, and we both had the box seat. The horses seemed to fly over the ground, up hill and down. We held our breath for fear; yet what seemed to us its element of danger made the drive so much the more exciting.

We were told the railroad would soon reach Washburn's. It will perhaps make it more comfortable for timid passengers, but for me give me the coach-and-six. I would not exchange that morning's drive for a ride in the finest palace car across the Continent. 


\title{
BOTANICAL DESCRIPTION.
}

\author{
BUTTERCUPS. \\ Ranunculacic Californicus. Benth.
}

More or less pilose; stems erect, or nearly so, twelve to eighteen inches high; root a cluster of somewhat thickened fibers; radical leaves, commonly pinnately ternate, the leaflets laciniately cut into three to seven lobes or parts, which are usually linear; flowers five to ten lines in diameter: petals usually ten to fourteen, narrowly obovate; sepals shorter than the petals, reflexed; akenes nearly two lines long, much flattened and with sharp edges; beak short and curved; heads compact, ovate or globular (Brewer \& Watson).

\section{EVENING PRIMROSE. \\ Enothera Californica. Watson.}

Hoary-pubescent and more or less villous; stems herbaceous from a running rootstock, decumbent, about a span long; leaves narrowly oblanceolate, acuminate, mostly petioled, sinuately toothed or irregularly pinnatifid two to four inches long; flowers large, white, becoming pinkish, axillary (Brewer \& Watson).

\section{BURR-CLOVER.}

\section{Orthocarpus linearilobus. Benth.}

A foot high, above with hirsute or somewhat hispid pubescence; leaves with few or several long and slender divisions; floral ones equaling the densely spicate flowers, the tips of their divisions commonly tinged with purple; calyx-lobes much longer than the tube and equaling that of the (purplish ?) corolla; sacs of the latter narrow, tapering gradually downward, much longer than deep; the ovate-subulate teeth thickish and short (Brewer \& Watson). 


\section{BABY BLUE-EYES.}

Nemophila Menziesii. Hook and Arn.

Leaves pinnately parted into seven to nine oblong and sometimes two to three lobed small divisions; corolla from light blue to nearly white, sprinkled with dark dots or spots, at least toward the center or (in cultivation) the spots confluent into a brownish purple eye; its scales narrow and wholly adherent by one edge, the other edge densely ciliate; seeds oval or oblong, either even or more or less tuberculate when ripe.

Low or shady grounds not uncommon. Corolla from half an inch to near an inch in diameter (Brewer \& Watson).

\section{YELLOW POPPY.}

\section{Eschscholtzia Californica. Cham.}

Usually one to one and one-half feet high and rather stout, branching; flowers large, two to four inches in diameter, usually brilliant orange in the center; torus dilated and often broadly rimmed; capsule two and one-half inches long, curved; seeds two-thirds of a line in diameter, reticulated; rhaphe obscure (Brewer \& Watson).

\section{LARKSPUR.}

\section{Delphinium Californicum. Torrey and Gray.}

Stems nearly or quite smooth below; leaves large, three to five-cleft, the divisions variously lobed; racemes strict, close-flowcred above; pedicels and flowers densely, velvety pubescent.

Dry soils near the coast. Stems stout, two or more feet high. Lower leaves three to five inches in diameter, usually deeply five-cleft, the divisions cuneate at base and laciniately toothed or lobed. Flowers commonly a light but dull blue, of ten more or less tinged with violet (Brewer \& Watson). 


\section{WILD-THRIFT.}

\section{Mesembryanthemum aquilaterale. Haworth.}

Perennial, with stout prostrate or ascending stems, and short ascending flowering branches, leaves very fleshy, opposite and clasping, linear, acutely triangular, one to three inches long, smooth; flowers solitary, red pedicellated or nearly sessile, about one and one-half inches in diameter; calyx tube turbinate, half an inch long or more, angled or terete; the larger lobes often as long; stigmas six to ten (Brewer \& Watson).

\section{CLUSTER LILY.}

\section{Brodica capitata. Benth.}

Leaves a foot long or more, two to ten lines wide, carinate, usually glaucous; scape a foot or two high, sometimes much shorter than the leaves; flowers few to many, nearly sessile or on pedicels one to six lines long; perianth rather broadly funnel-form, six to ten lines long, from blue to purple or white; inner anthers nearly sessile, linear, two lines long, slightly shorter than the oblong lanceolate appendages; the outer smaller, on short, naked filaments broadly dilated at the base; capsule ovate, sessile, three lines long; beaked by the slender style nearly as long; seeds several in each cell, two lines long (Brewer \& Watson).

\section{VIOLET.}

\section{Viola pedunculata. Torrey and Gray.}

Nearly glabrous, or somewhat puberulent, the ascending stems two to six inches high, from a slender decumbent or procumbent base; leaves rhombic-cordate, with base usually truncate or abruptly cuneate, obtuse, one-half to one and one half inches long, often small, coarsely crenate; stipules foliaceous, narrowly lanceolate, entire or gashed; peduncles much exceeding the leaves; flowers showy, deep yellow; sepals oblong-lanceolate, obtuse or acute; petals six to nine lines long, the upper more or less tinged with brown, on the outside, the others veined with purple, lateral petals bearded; capsule oblong-ovate, five to six lines long, glabrous (Brewer \& Watson). 


\section{WILD VERBENA.}

\section{Abronia umbellata. Lam.}

Perennial, prostrate, slender, viscidly puberulent, the stems often elongated, one to three feet high ; leaves nearly glabrous, ovate to narrowly oblong, one to one and onehalf inches long, attenuate into a slender petiole, obtuse, the margin often somewhat sinuate; peduncles two to six inches long; involucral bracts, small, narrowly lanceolate, two to three lines long, ten to fifteen-flowered; perianth rose-colored, six to eight lines long, with emarginate lobes; fruit four to five lines long, nearly glabrous, the body oblong, attenuate at each end ; the thin wings nearly as long, rounded, broadest above and often truncate, narrowing downward to the base of the fruit; akene one and one-half lines long (Brewer \& Watson).

\section{BLUE-BELLS.}

\section{Phacelia Whitlavia. Gray.}

About a foot high, loosely branching, hirsute and glandular, .eaves ovate or deltoid, obtusely and incisely toothed, longer than the petiole; raceme loose and elongating; tube of the violet (or rarely white) corolla an inch or so long, twice or thrice the length of the rounded lobes and of the narrow calyx lobes; stamens conspicuously exserted (Brewer \& Watson).

\section{SNAP-DRAGON.}

\section{Mimulus lutens. Linn.}

Erect or diffuse, from a fibrous annual root, and commonly perennial by short stolons, glabrous or merely puberulent; the ordinary erect form a foot or two or even three or four feet high; leaves ovate, oval or roundish, sometimes cordate, several-nerved from base or near it, sharply and irregularly dentate, or the lower occasionally lyrate-laciniate; the upper sessile; the floral becoming small and bract-like, often connate; peduncles becoming racemose, equaling or shorter than the flower; calyx becoming ovate-inflated in fruit and the upper tooth conspicuously largest; corolla from one and one-fourth to one and three-fourths of an inch long, yellow, often clotted within and sometimes blotched with brown-red or purple (Brewer \& W Watson). 


\section{SHOOTING STAR.}

\section{Dodecatheon Mcadia. Linn.}

Leaves varying from obovate to lanceolate, entire or more or less toothed; scope three to fifteen inches high; umbel two to twenty flowered. So far as we can make out only one species occurs, which extends across the continent, and on the Pacific side through fully forty degrees of latitude (viz.: from Gaudaloupe Island, Lower California, to those within Behring Straits), varying inmensely and inextricably. The Pacific forms (which usually have rather shorter or blunter anthers than the Atlantic), may, as to their leading features, be mainly but loosely arranged under many varieties (Brewer \& Watson).

\section{WILD PEONY.}

\section{Pconia Brownit. Dougl.}

Leaves thick, one or two-ternately, compound, the leaflets ternately and pinnately lobed; follicles three to five. San Bernardino to Vancouver and Western Utah, but rare east of the Sierra Nevada. Stems ten to eighteen inches high, smooth, striate, erect when growing, but gradually bending over until maturity, when the follicles rest on the ground. Leaves glaucous beneath, either glaucous or glabrous above. Sepals green, sometimes quite unequal in size. Petals scarcely larger than the sepals, thick and leathery, dull, dark red. Follicles very leathery, smooth, erect, one to one and one-half inches long. This plant endures a great range of station and climate, from wet to very dry soils, and from the hot plains of Southern California to near the confines of perpetual snow on the mountains (Brewer \& Watson).

\section{CHINESE CIGARETTE BLOSSOM.}

\section{Nicotiana glauca. Graham.}

Arborescent, soft-woody below, glaucous and glabrous; leaves long-petioled, ovate and subio-ordate, entire or repand ; flowers loosely paniculate ; corolla greenish, becoming yellow, inch or two long, tubular, contracted at throat, and with erect five-crenate limb not longer than the orifice.-Bot. Mag. t. 2837. Native of Buenos Ayres, not rare in cultivation, rather widely naturalized in S. California and S. Texas. 


\section{WILD HELIOTROPE.}

\section{Phacelia tanacetifolia. Benth.}

Erect, one to three feet high, roughish-hirsute or hispid; leaves nine to seventeen, divided into linear or oblong-linear once or twice pinnately-parted or cleft divisions, all sessile or nearly so; the lobes small and mostly linear-oblong; spikes cymosely clustered, at length elongated; the very short pedicels ascending or erect; corolla light violet or bluish; stamens and style usually very much exserted; calyx-lobes linear or linear spatulate, not twice the length of the oval or oblong-oval capsule (Brewer \& Watson).

\section{TIDY-TIPS.}

\section{Gaillardia aristata. Pursh.}

Perennial, a span to a foot or more high; lowest leaves spatulate or oblanceolate, sometimes pinnatifid, tapering into petioles; the upper sessile and often entire; bristles on the receptacle slender, much longer than the akenes, sometimes almost as long as the corolla; rays ten to eighteen, an inch or more in length, yellow, sometimes tinged with purple at the very base.

Plains and open ground, common through Oregon, extending to the Saskatchewan region.

\section{SNOW PLANT.}

Sarcodes sanguinea. Torrey.

A stout, fleshy herb, a span or two in height, of a bright red color, more or less glandular-pubescent, thickly clothed, at least up to the raceme, with firm, fleshy scales; the lower ones ovate and closely imbricated, the upper gradually more scattered, narrower, and passing into the linear bracts, which mostly exceed the flowers, their margins glandular-ciliate; pedicels erect, at least the upper ones short; corolla half an inch long, rather fleshy, glabrous.

In coniferous forests, especially those of Sequoia and Abies, through the Sierra Nevada, from four thousand to nine thousand feet, shooting forth and flowering as soon as the snow melts away (Brewer \& Watson). 
FORGET-ME-NOT.

\section{Mcrtensia Sibirica. Don.}

Smooth and glabrous or nearly so, a foot or more high, rather succulent, leafy; leaves pale, ovate-lanceolate or oblong, acute, two to five inches long, or the lowest larger and broader, minutely ciliate; flowers at first clustered; corolla half an inch or less long, much longer than the oblong, obtuse divisions of the calyx; the five-cleft limb about half the length of the tube; stamens protruding out of the throat, and the capillary style early projecting beyond the lobes (Brewer \& Watson).

\section{WOOD-LILY.}

\section{Erythronium grandiflorum. Pursh.}

Corm narrow, often two inches long; leaves not mottled, always closely approximate, oblong-lanceolate, acute or acutish and with broad and usually short petioles, three to four inches long, by one to two wide; flowers solitary, or often in a raceme of two or six or nore, yellow or cream color, with a more or less orange base; segments lanceolate, and somewhat acuminate, strongly recurved, one to two inches long, filaments long and slender; anthers three to five lines long; ovary and capsule narrowly oblong, narrowing to a short stipe; capsule an inch long or more (Brewer \& Watson).

\section{AZALEA.}

Rhododcudron occidcntale. Gray.

Shrub two to six feet high, leaves obovate-oblong, sometimes approaching lanceolate, bright green and shining above, minutely pubescent, glabrate, the margins minutely hispidciliate; scales of the flower-bud somewhat canescent ; flowers appearing after the leaves; sepals distinct, oblong or oval, conspicuous; corolla minutely viscid, pubescent outside, white (sometimes slightly rosy), with the upper lobe yellow inside; the narrow funnelform tube equaling the deeply five-cleft slightly irregular limb; the lobes ovate; stamens and style much exserted, moderately curved; capsule oblong (Brewer \& Watson). 


\section{SPOTTED LILY.}

\section{Lilium Columbianum. Hanson.}

Bulb small (one and one-half to two inches in diameter), with lanceolate, acute, closely-appressed whitish scales; stems two to three feet high or more, slender; leaves in whorls of five to nine or sometimes more, the upper and lower scattered, oblanceolate, two to four inches long and six to fifteen lines wide, acute, smooth; flowers few to many, scattered, on slender, curving, more or less divergent pedicels, three to six inches long; segments one and one-half to two inches long and four to six lines wide, strongly revolute, bright reddish orange, thickly-spotted; stamens about equaling the style, twelve to fifteen lines long, with yellow, oblong anthers, two to three lines long; capsule short, oblong, an inch long, acutely six-angled (Brewer \& Watson).

\section{SALMON-BLOSSOM AND PINK GRASS.}

\section{Rubus Nutkanus. Mocino.}

Stems erect or drooping, three to eight feet high; bark green and smooth or more or less glandular-pubescent, becoming brown and shreddy; leaves palmately and nearly equally five-lobed, cordate at base, unequally serrate, four to twelve inches broad, the lobes acute or acuminate, glabrous or somewhat tomentose, the veins beneath as well a's - the petioles and peduncles usually more or less hispid with gland-tipped hairs; stipules lanceolate acuminate; flowers rather few, white, an inch or two broad; calyx densely tomentose, carpels very numerous, tomentose; fruit large and pleasantly flavored (Brewer \& Watson).

\section{MARIPOSA LILY.}

\section{Calochortus. Pursh.}

Perianth deciduous, of six distinct species; segments, the three outer lanceolate, greenish and more or less sepaloid, the inner mostly broadly cuneate-obovate, usually with a conspicuous glandular pit near the base and very variously colored.

This is perhaps a form of Calochortus luteus. Dougl. 





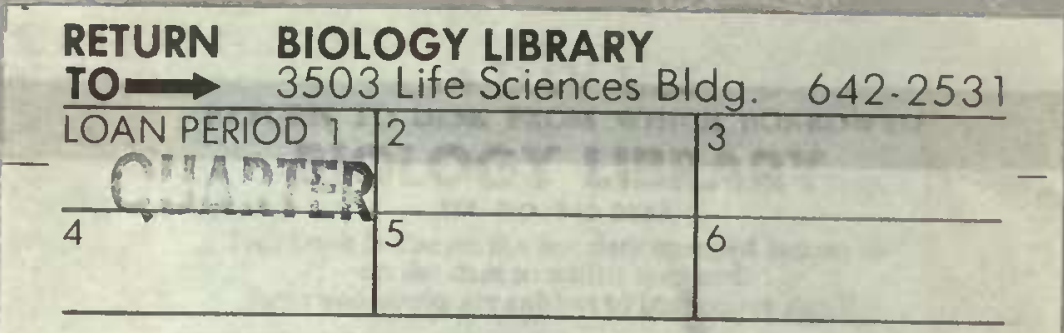

ALL BOOKS MAY BE RECALLED AFTER 7 DAYS Renewed books are subject to immediate recall

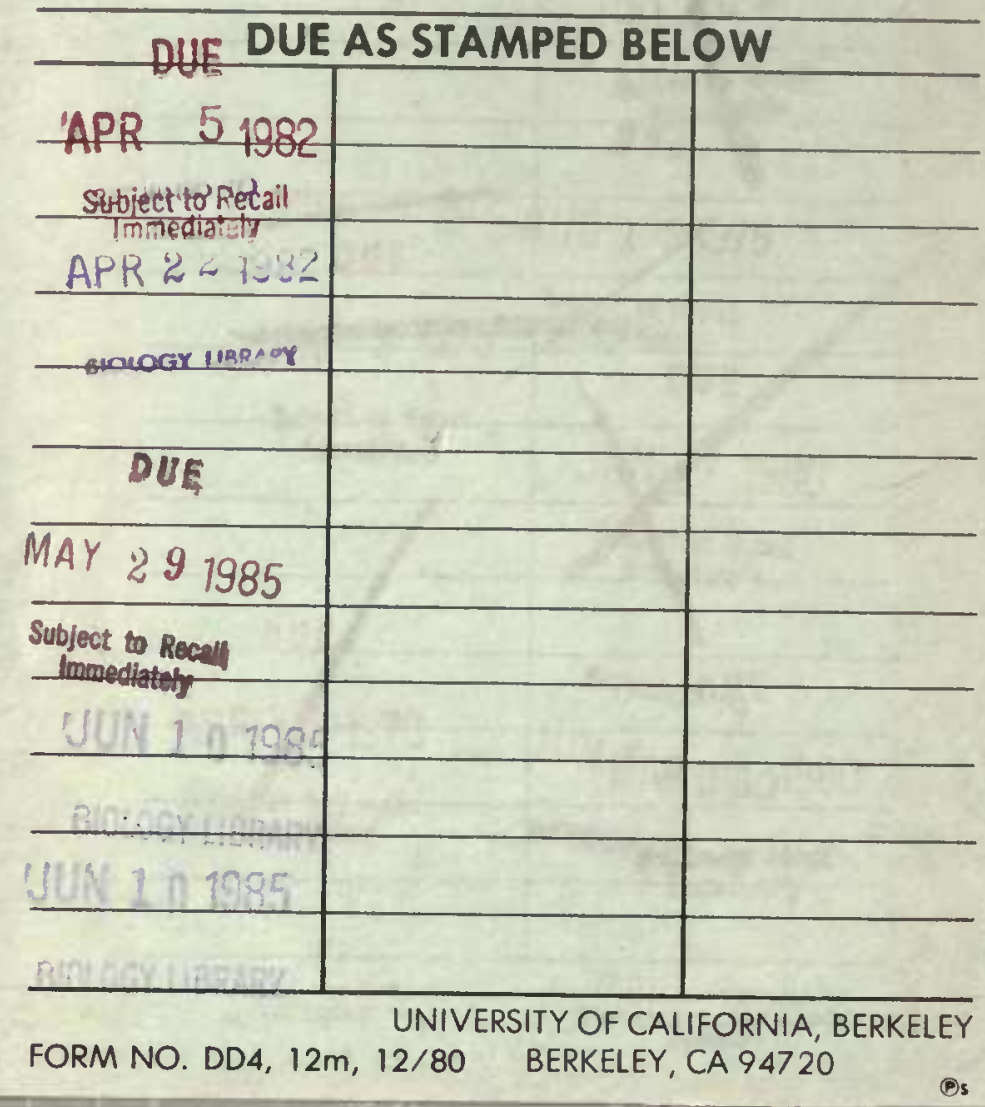



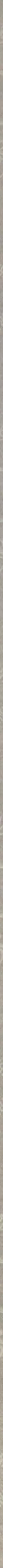
